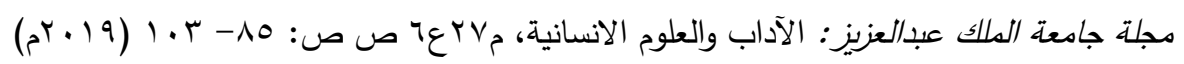

\title{
رؤية المستشرقين لمكانة الإجماع، وحقيقته، من خلال دائرة المعارف الإسلامية دراسة نقدية
}

\author{
هنادي بنت رشيد بن رشيد الصاعدي \\ بحث مقّم في ملتقى الفعاليات العلدية الأول

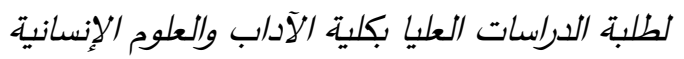 \\ بجامعة الملك عبد العزيز
}

مستخلص. الحمد لله رب العالمين، والصلاة والسلام على خاتم الأنبياء والمرسلين، وبعد:

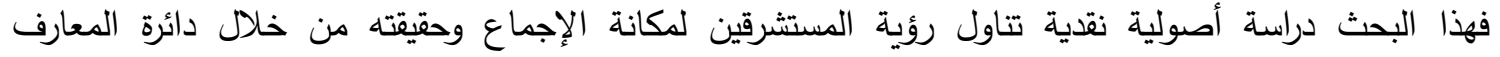

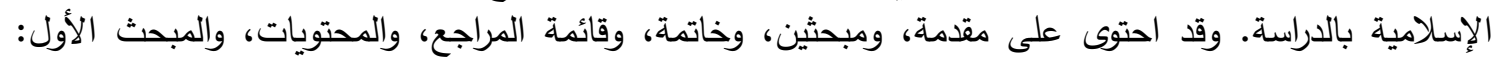

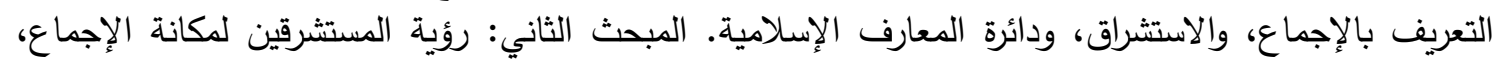

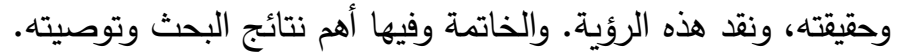

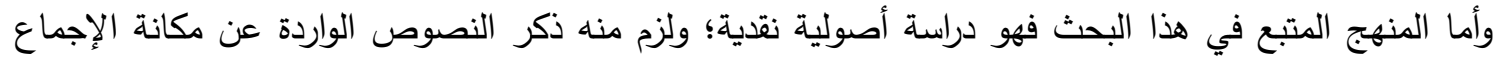

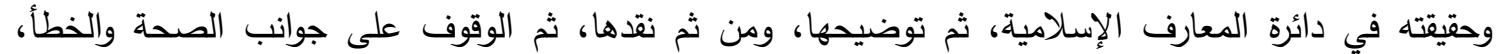
ومناقشتها. وأهم نتيجة في هذا البحث: أن ما ورد في دائرة المعارف الإسلامية عن مكانة الإجماع وحقيقته منحرف انحرافاً

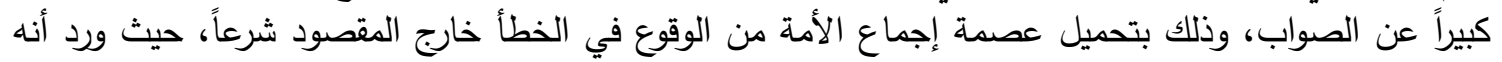

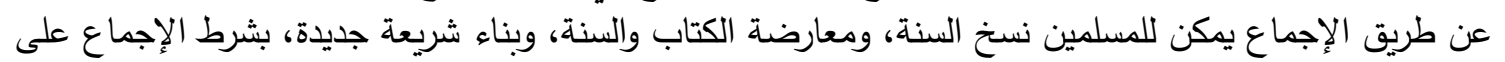
ذلك، والصحيح غير ذلك تماماً.

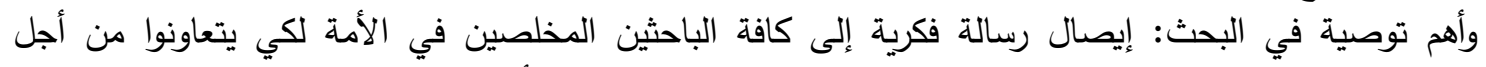
استبدال هذه الدائرة بدائرة معارف إسلامية، يكتبها ويشرف عليها إلها المسلمون أنفسهم.

فإن مما لا شكّ فيه أن الشريعة الإسلامية شريعة خالدة، وهي خاتمة الشرائع، وصالحة لكل زمان ومكان إلى أن يرث الله الأرض ومن عليها، وامتازت هذه الشريعة بتعدد المصادر التي يستضيء بها المسلم، فكان الكتاب، وكانت السنة، وكان إجماع

\section{المقدمة}

الحمد لله رب العالمين، الهادي إلى الصراط المستقيم، والصلاة والسلام على خاتم النبيين، وعلى لهى آله وصحبه ومن تبعه بإحسان إلى يوم الدين.

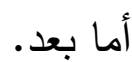


خطورة خلال القرن العشرين، بل هي تمثل خلاصة جهود المستشرقين في الدراسات الإسلامية خلال القرون الميلادية الثلاثة الأخيرة، وتأليفهم لها منظّم، يسير وفق خطط تشرف عليها مؤسسات علمية

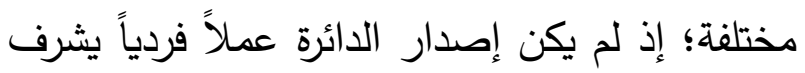
عليه بعض المستشرقين المنتمين إلى قطر واحد أو إلى لغة واحدة، بل كان عملاً جماعياً دولياً عقدت له له له المؤتمرات، وتتادى من أجله المستشرقون من شتى

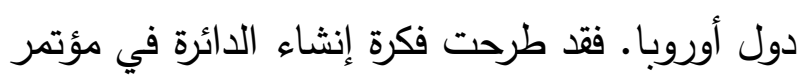

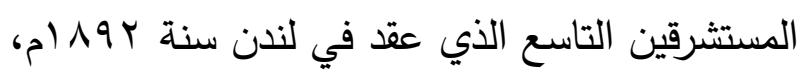
وتوالت دراسة هذه الفكرة في ثلاثة مؤتمرات متتالية

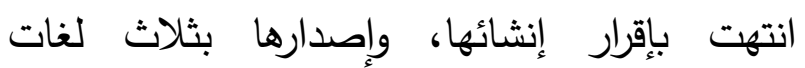
أوروبية. وقد تم إصدار نموذج منها عُرض في إنراز مؤتمر المستشرقين الثاني عشر الذي عقد في روما

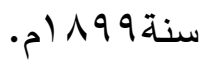
وتعتبر دائرة المعارف الإسلامية من أخطر الجهود العمية للمستشرقين؛ نظراً لما تناولته من تعريف العنئ بالإسلام، وبالشعوب الإسلامية من وجهة النظر لفران الاستشراقية دون أن يكون للمسلمين شأن يذكر في كتابة مادتها العمية أو مراجعتها، وبذلك احتوت دون على أخطاء كبيرة، ودسائس مريبة. ولقد وعد الله سبحانه وتعالى بحفظ هذا الدين، و قيّض لله من يقوم ببيانه، وعرضنه، والدفاع عنه من غير كلل ولا ملل، فقامت سلسلة من الدراسات والمقالات بالرد على ما ورد في الدائرة من خبايا ودسائس في عدد من موضوعاتها، كالعقيدة، وفقه العبادات، وفقه الأسرة، وغيرها، أما مكانة الإجماع وحقيقته فكانت هنالك محاولات في الرد على ما ورد حوله؛ ولكن لم تكن دراسة علمية تقوم بجمع ما
مجتهدي الأمة، وكذلك القياس الشرعي، وغير ذلك من الأدلة الثرعية. وللإجماع مكانة كبرى بين مصادر التشريع الإسلامي؛ فهو أحد الأدلة المتفق على حجيتها في الجملة، وأحد أهم أربعة مصادر للأحكام الشرعية؛ بل يعدّ الإجماع نائب عن النبوة، قال ابن عقيل ('): "والإجماع دليل من أدلة الشرع، نائب عن النبوة، فكل قول ومذهب يؤدي إلى تعطيله باطل في

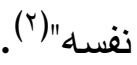

ومعلوم أن الدين الإسلامي منذ ظهوره، وخصومه في عداء سافر له، وتشكيك لا ينقطع لأتباعد، في كافة علومه وفنونه، وقد حاكى خصومُ الإسلام اليوم

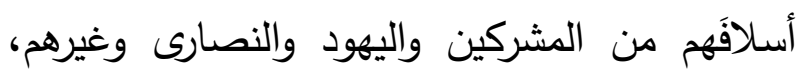
وكرروا ما قالوا بعبارات جديدة وصيخ مختلفة. ولقد أسست في هذا العصر العديد من المعاهد والمراكز والجامعات الاستشراقية، من أهدافها محاربة هدية الإسلام بشتى الطرق، ومن هذه الطرق التأليف الموسوعي ضد الإسلام والمسلمين، ومن أهم إصداراتها (دائرة المعارف الإسلامية) التي تعدّ من الإنديل أكبر الدراسات الاستشراقية عن الإسلام، وأعظمها تعدا هنا

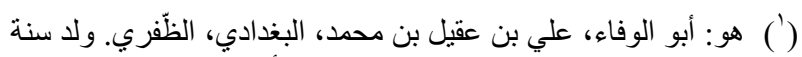

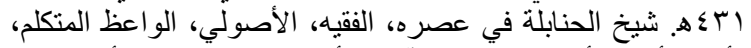

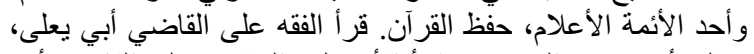

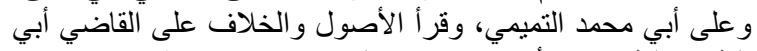

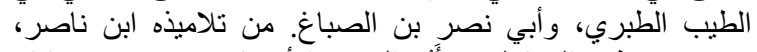

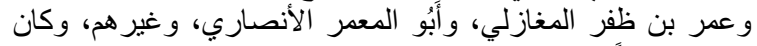

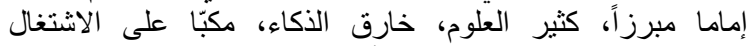

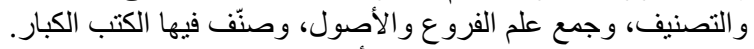
لله من الكتب: الفنون، و الو اضح في أصول الصول الفقه، وكفاية الدفتي. توفي لكبي

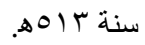

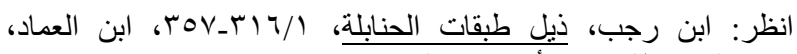

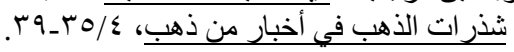
(') (ابن عقيل، الو اضح في أصول الفقه، 101/0. 
• عدم إشراف علماء المسلمين على كتابة مواد الائرة، بل وعدم اشتراكهم في كتابة موادها

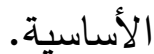

• رغبة الباحثة في خدمة علم أصول الفقه، وما

$$
\text { يمليه عليها واجب الدفاع عنه. }
$$$$
\text { مخطط البحث: }
$$

يتكون البحث من مقدمة ومبحثين وخاتمة وقائمة

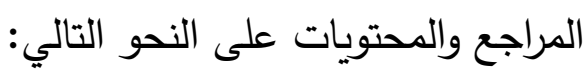
المقدمة وتحتوي على: أهمية البحث، وأسباب الهوبات اختياره، ومخططه، ومنهجه.

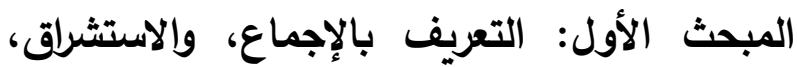
ودائرة المعارف الإسلامية، وفيه ثلاثة مطالب: المطلب الأول: التعريف بالإجماع. المطلب الثاني: التعريف بالاستشراق. المطلب الثالث: التعريف بدائرة المعارف الإسلامية.

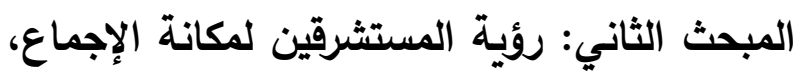
وحقيقته، ونقد هذه الرؤية، وفيه مطلبان:

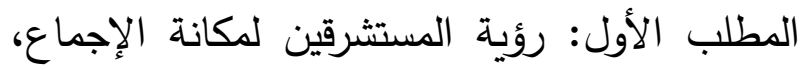

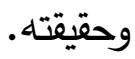

المطلب الثاني: نقد هذه الرؤية.

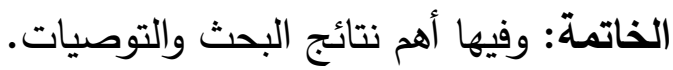
قائمة المراجع. قائمة المحتويات. منهج البحث: ا. ذكر النصوص الواردة عن مكانة الإجماع وحقيقته في دائرة المعارف الإسلامية، ثم توضيح

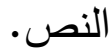
r. نقد النص المتضمن للمسألة، وذلك ببيان آراء الأصوليين حول المسألة، ثم الوقوف على جوانب
يتعلق بذلك وتحليله ونقض الأخطاء الواردة فيه،

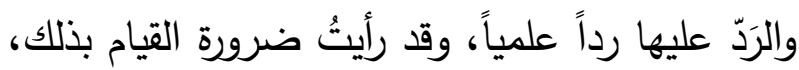

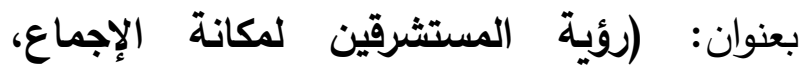
وحقيقته، من خلال دائرة المعارف الإسلامية دراسة نقاية).

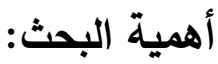
تكمن أهمية هذا البحث في جانبين:

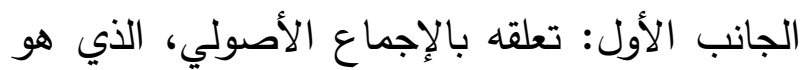
معصوم عن الخطأ، ومن أهم الأدلة الشرعية. الجانب الثاني: تعلقه بدائرة المعارف الإسلامية التي التي

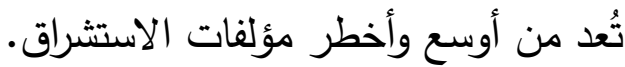

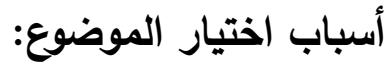
الذي دفع الباحثة لدراسة هذا الموضوع والكتابة فيه، أمور عدة، هي: • ما سبق بيانه من أهمية الموضوع. خطورة دائرة المعارف الإسلامية، والمكانةُ التي لتئي

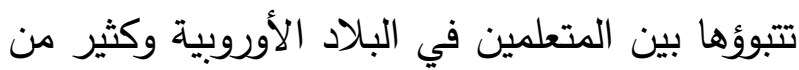
البلاد الإسلامية، فقد اتخذها كثير من الناس مرجعاً

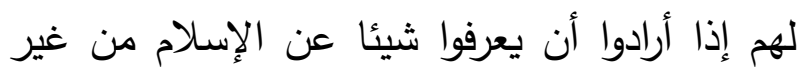
المسلمين ومن بعض المسلمين. قبول وإعجاب بعض الباحثين العرب والمسلمين بدائرة المعارف الإسلامية، ومن ذلك الإطراء الذي لإبي سطره مترجمو الطبعة الأولى من هذه الموسوعة (').

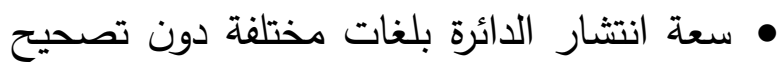
أو تنقيح. • التصوير المشوّه والتحريف المتعدد لحقيقة الإجماع في دائرة المعارف الإسلامية. 
بأنه: "اتفاق مجتهدي عصر من هذه الأمة بعد وفاة شبينا محمد شئس

اتفاق مجتهدي عصر: قيد في التعريف اختصّ فيه الاتفاق بالمجتهدين دون غيرهم، في عصر من العصور (ن).

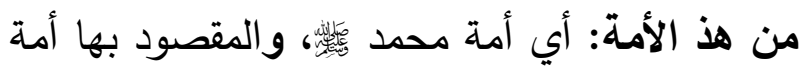

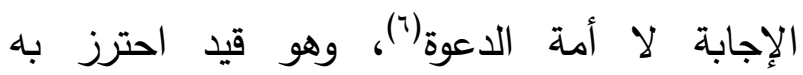
الأصوليون عن اتفاق الأمم السابقة، ومجتهدي الشرائع السالفة، وكذلك الكفّار عموماً( (Y).

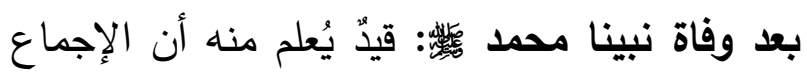

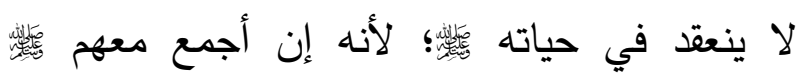
فالعبرة تكون في قوله عليه الصلاة والسلام (^). على أمر ديني: قيد يخص الأمر المجمع عليه بأنه يتعلق بالدين لذاته أصلاً أو فرعاً، وخرج بذلك الكئ اتفاق

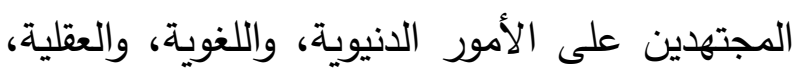
وغيرها(9) () حنبل، ع Vام، المختصر في أصول الفقه على مذهب الإمام أحمد بن (") انظر : التفتاز اني، شرح التلويح على التوضيح لمتن التنقيح في أصول

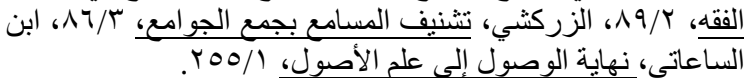

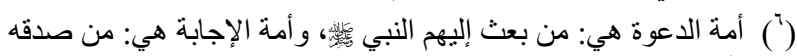
وآمن بها، وهم المسلمون.

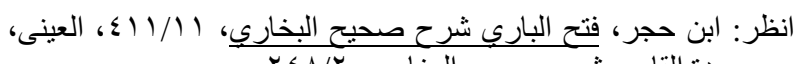

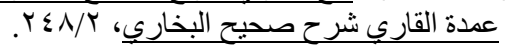

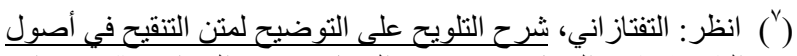

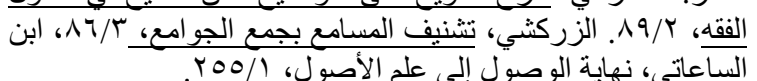

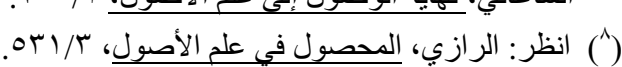

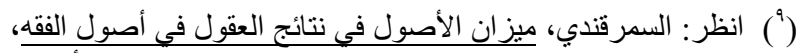

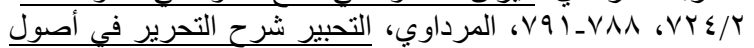

الصحة والخطأ والنقص الواردة في دائرة المعارف الإسلامية حول المسألة، ومناقشتها. r. عزو الآيات إلى سورها، وذكر رقمها في السورة، مع كتابتها بالرسم العثماني. ع. التعريف بالمصطلحات الواردة في البحث من بن مظانها المعتمدة. هـ ترجمة الأعلام الوارد ذكرهم في البحث، باستثناء أئمة المذاهب الأربعة. وفي الختام، أسأل الله القَبول والرحمة والغفران لكل من ورد اسمه في هذا البحث من المسلمين، وكاتبه، وقارئه، والناقل عنه، ولعامة المسلمين والمسلمات، وصلى الله وسلم وبارك على محمد وعلى آله وله وأصحابه الطيبين الطاهرين، ومن تبعهم بإحسان إلى ولى يوم الدين وآخر دعوانا أن الحمد لله رب العالمين. المبحث الأول: التعريف بالإجماع، والاستثراق، ودائرة المعارف الإسلامية المطلب الأول: التعريف بالإجماع:

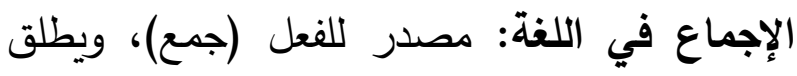

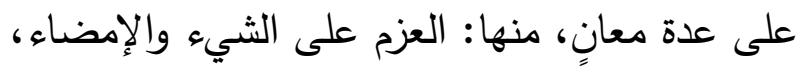

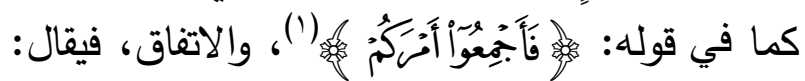
أجمع القوم إذا صاروا ذوي جمع (؟).

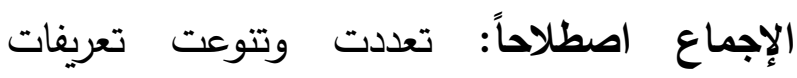
الأصوليين للإجماع|(r)، ومن أجود تعريفاتهم لله قولهم تصني

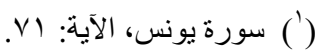

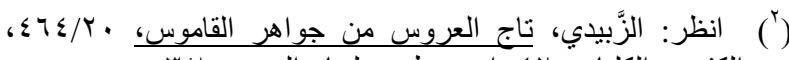

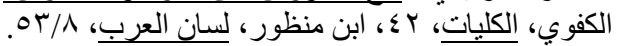

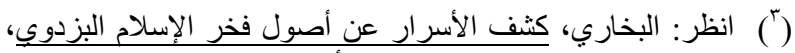

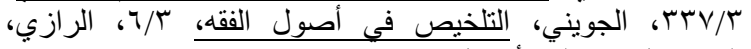

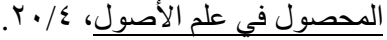


والمستشرق: اسم فاعل، فهو من يقوم بالدراسات المتعلقة بالشرق، (على اختلاف رؤية الباحثين للمراد بهذه الدراسات، والقائم بها).

المطلب الثالث: التعريف بدائرة المعارف

الإسـلامية:

دائرة المعارف، أو موسوعة المعارف هي من

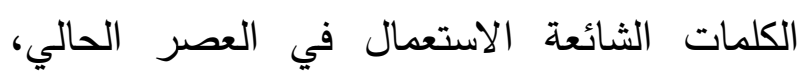
والتي تدل على الكتاب الذي يحوي معارف شاملة ومتتوعة في موضوع واحد، أو في موضوعات متعددة (7).

ودائرة المعارف الإسلامية هي: "موسوعة أكاديمية تعني بكل ما يتصل بالحضارة الإسلامية، سواء من

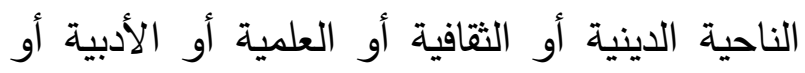
السياسية أو الجغرافية على امتداد العصور ، بما في ذلك العصر السابق للإسلام" (v). وهي موسوعة أُخرجت للقراء في بداية القرن الرابع عشر الهجري، العشرين ميلادي، على هيئة أبحاث

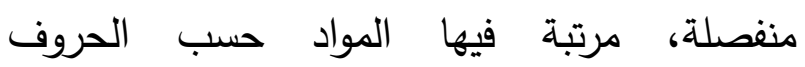
الهجائية(^). وقد حاكى كاتبو دائرة المعارف الإسلامية الأسلوبَ المتبع عند أصحاب المعاجم اللغوية، ودوائر المعارف العربية، والتي اعتمدت الترتيب الهجائي

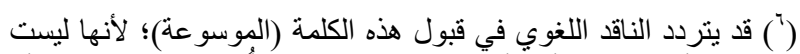

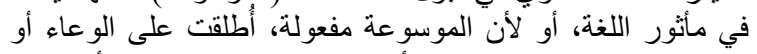

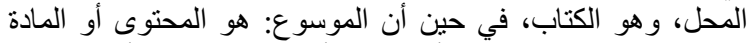

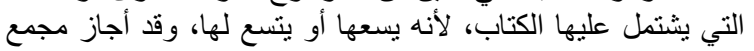

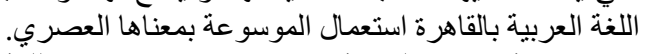

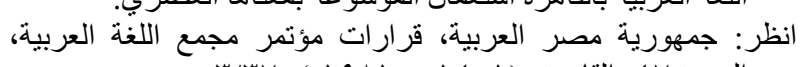

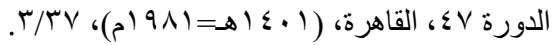

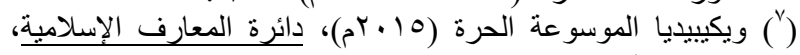

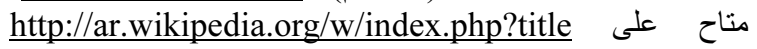

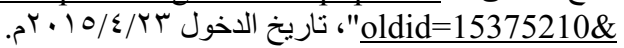

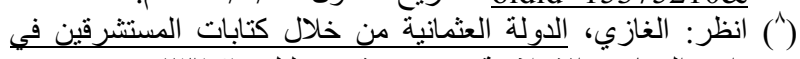

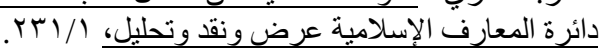

المطلب الثاني: التعريف بالاستشراق: الاستشراق لغة: مأخوذ من "شرق" يقال: شرقت

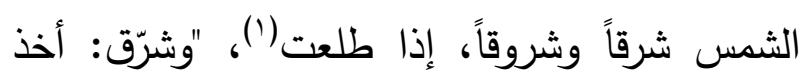
ناحية المشرق"(؟). وباضضافة الحروف الثلاثة (الألف والسين والتاء) إلى الكلمة يصبح معناها: أدخل نفسه في أهل الشرق وصار منهم(r). الاستشراق اصطلاحاً: له عدة تعريفات عند الباحثين

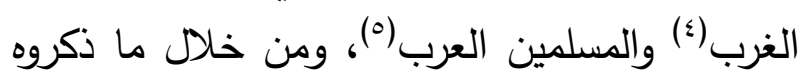
يمكن تعريف الاستشراق بأنه: الاراسات المتعلقة بالثرق الإسلامي من غير الثرقيين في كافة

جوانب الحياة. شرح التعريف: الاراسات المتعلقة بالثرق الإسلامي: أي الخاصة بالشعوب الإسلامية، ويخرج منها الدراسات المتعلقة باليابانيين أو الصينين أو غيرهم؛ لأن اهتمامات

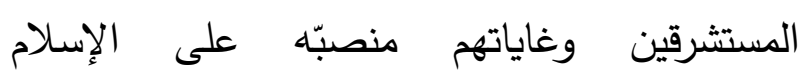
وموضوعاته غالباً. من غير الثرقيين: أي سواء كان الدارسون أوربيون أو أمريكيون أو روسيون أو غيرهم. في كافة جوانب الحياة: وتشمل الحياة الدينية والسياسية والاجتماعية والاقتصادية وغيرها.

(') انظر: الرازي، مختار الصحاح، گمب، ابن فارس، معجم مقاييس

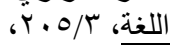

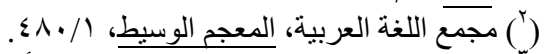

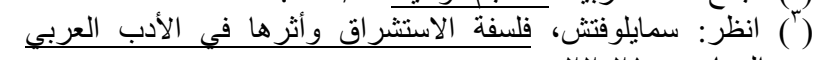

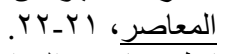

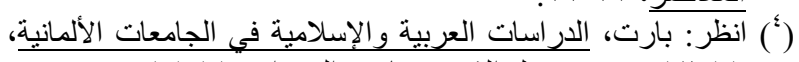

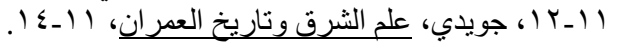

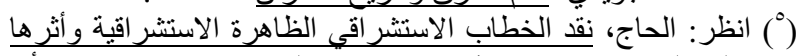

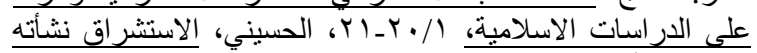

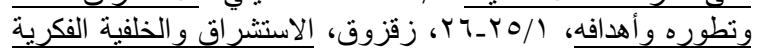

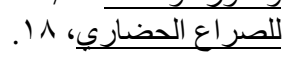


جزءاً من السنة، وأعجب من هذا أن الاعتقاد بعصمة النبي قد جعل الإجماع ينحرف عن نصوص واضحة في القرآن الكريم. فلم يقتصر الإجماع هنا على تقرير أمور لم تكن مقررة من قبل فحسب؛ بل غيّر عقائد ثابتة وهامة جداً تغييراً تاماً. وعلى هذا فهر فهو يعد اليوم عند الكثيرين -مسلمين وغير مسلمينوسيلة فعالة للإصلاح. فهم يقولون إن المسلمين يستطيعون أن يجعلوا من الإسلام ما شاءوا على شريطة أن يكونوا مجمعين. على أن الآراء غير متفقة فيما يمكن أن ينتظر مئور

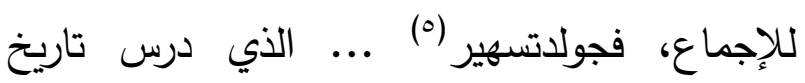

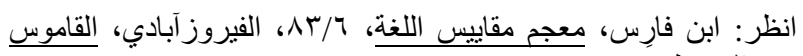

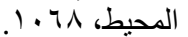

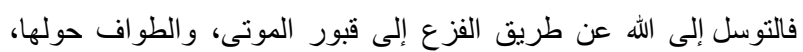

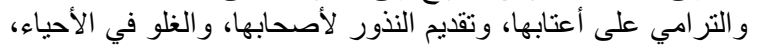

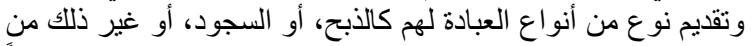

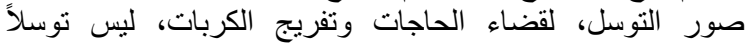

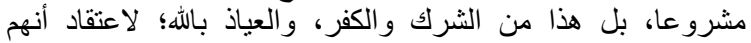

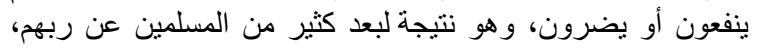
وجهلهم بدينهم.

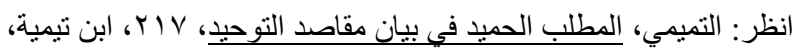

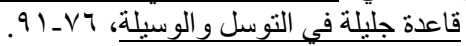

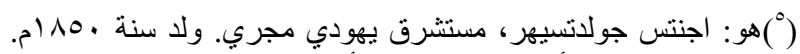

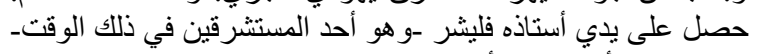

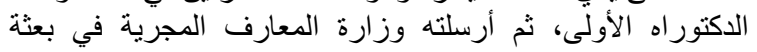

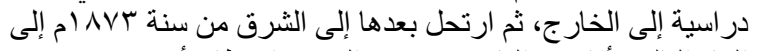

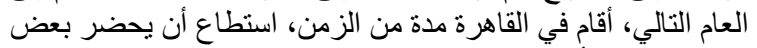

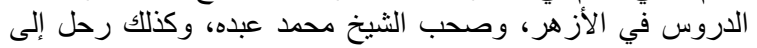

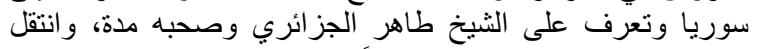

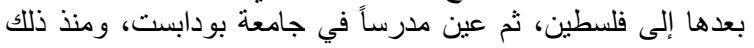

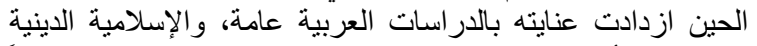

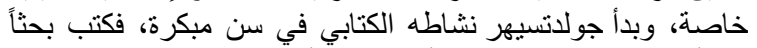

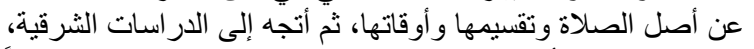

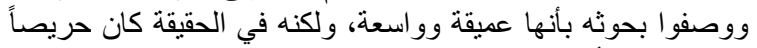

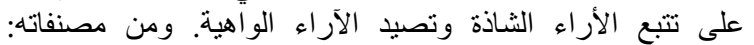

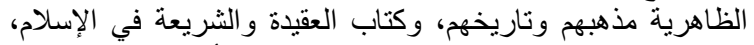

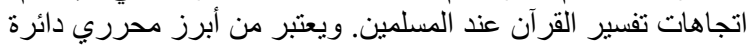

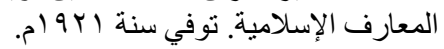

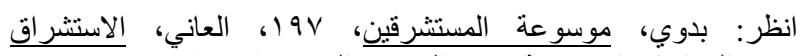

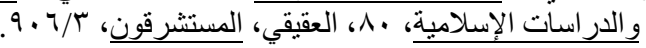

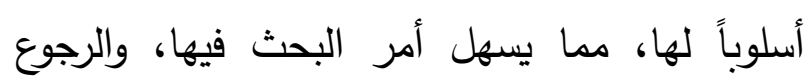
إليها، والاستفادة منها (')

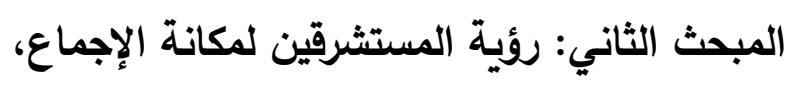
وحقيقته، ونقد هذه الرؤية

المطلب الأول: رؤية المستشرقين لمكانة الإجماع، ودقئ لرؤية وحقيقته:

أولاً: النصوص في دائرة المعارف الإسلامية:

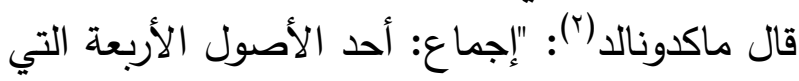

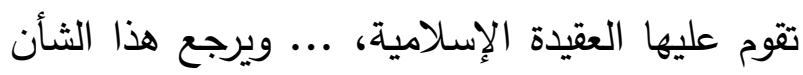
للإجماع إلى العصمة من الوقوع في الخطأ، وهي

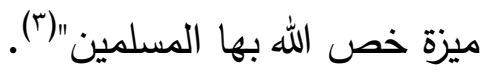
وقال: "وعلى هذا فإنه يكون في مقدور الناس أن

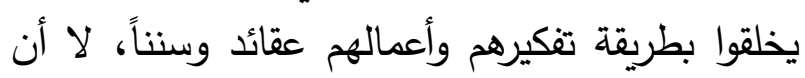

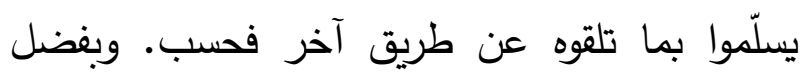
الإجماع أصبح ما كان في أول أمره بدعة (أي فعله فلهون

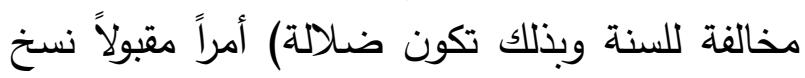

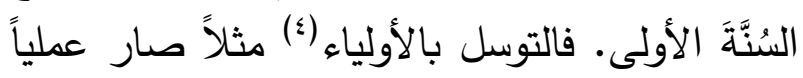

(') انظر: سمايلوفتش، فلسفة الاستشراف وأثرها في الأدب العربي

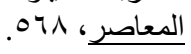

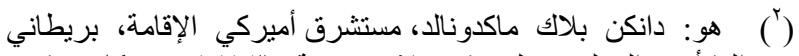

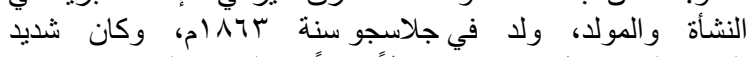

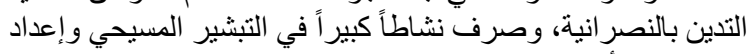

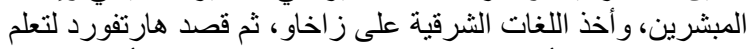

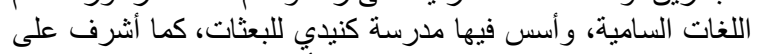

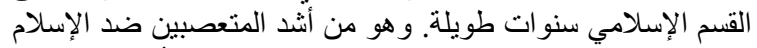

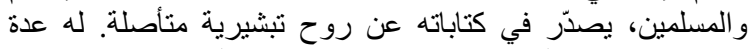

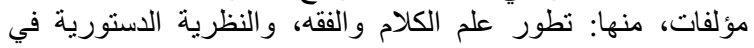

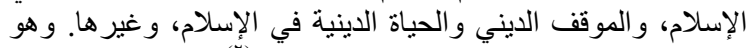

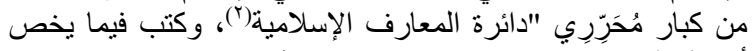

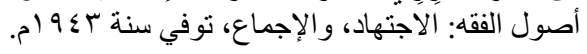

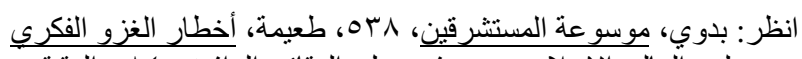

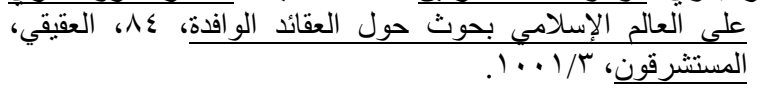

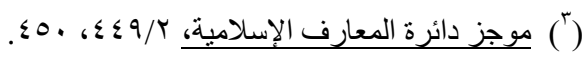

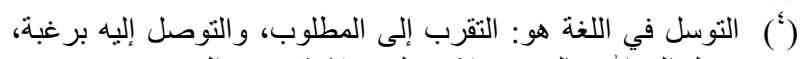
ووسل إلى الله تعالى توسيلا: عمل اللغ عملا تقرب به إله الليه. 
المطلب الثاني: نقد هذه الرؤية:

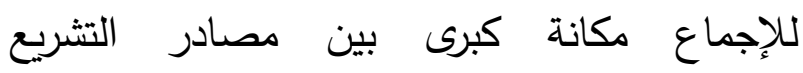

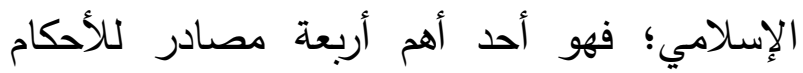

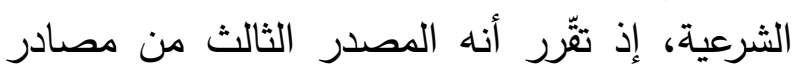

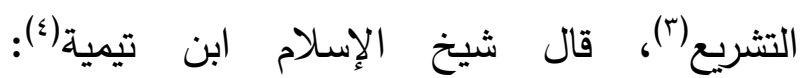

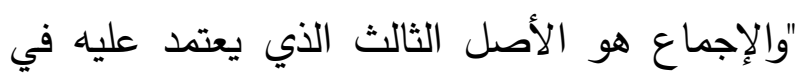
العلم والدين" (o). وقد اتفق أئعة المذاهب الأربعة على الأخذ به في

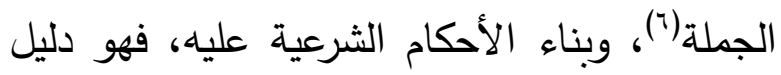

قاطع للنزاع. كما أن الإجماع مظهر من مظاهر الجماعة؛ لأنه يحقق وحدة الأمة، ويقي من مغبّة الفرقة والاختلاف. من من الاعة لأه

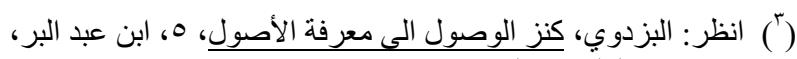

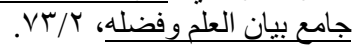

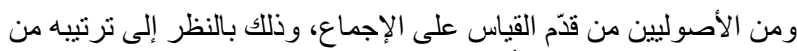

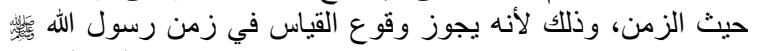

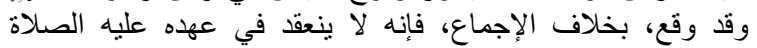

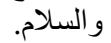

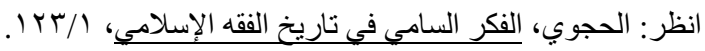

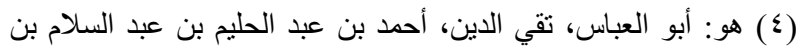

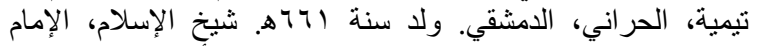

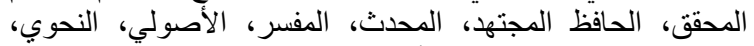

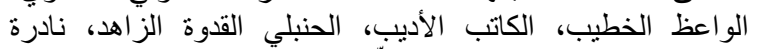

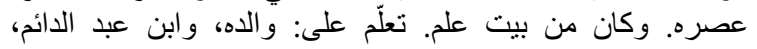

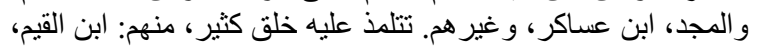

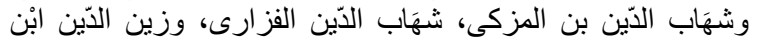

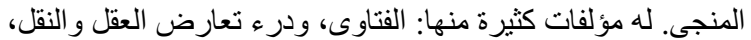

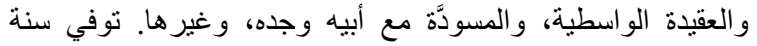
$\Delta \vee Y \Lambda$

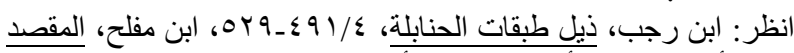

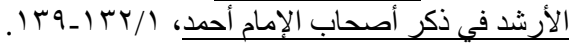

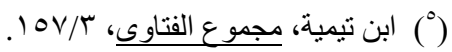

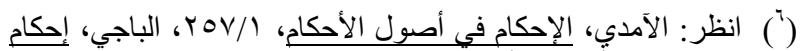

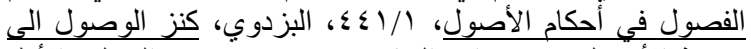

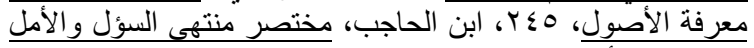

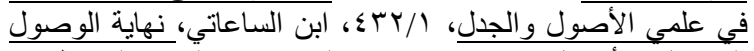

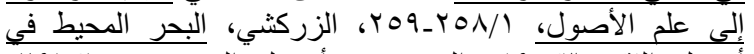

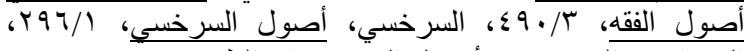

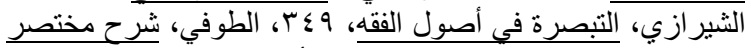

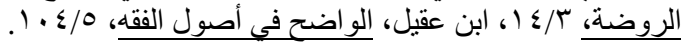

الإجماع يعتقد أنه يمكن أن يكون له شأن كبير،

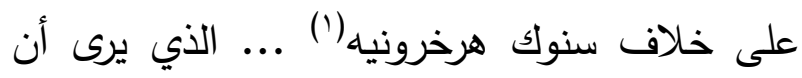
الفقه قد جمد لذلك فلا رجاء في الإجماع"(؟). ثانياً: إيضاح النصوص: ذكر ماكدونالد أن الإجماع أحد الأصول الأبربعة التي تقوم عليها العقيدة الإسلامية (الكتاب، والسنة، الإعاع الإنة

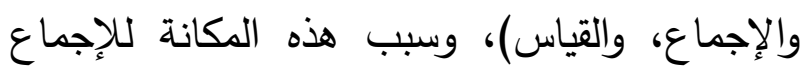

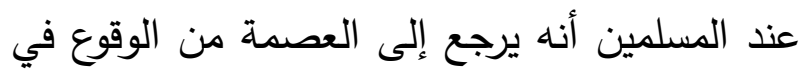
الخطأ، وهي ميزة خص الله بها المسلمين. وبذا يمكن للمسلمين عن طريق الإجماع: - التوفيق والتقريب بين السنة والبدع المستحدثة، بشرط الإجماع.

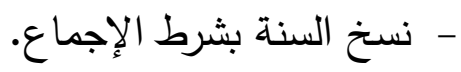
- معارضة الكتاب والسنة بشرط الإجماع.

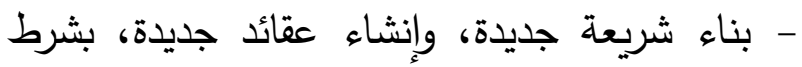
الإجماع على ذلك.

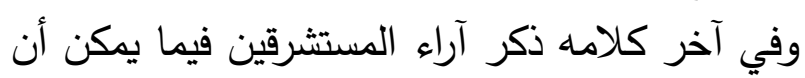

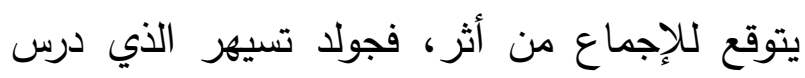

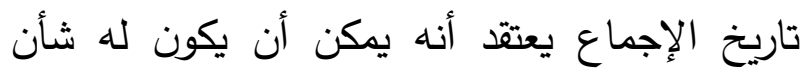

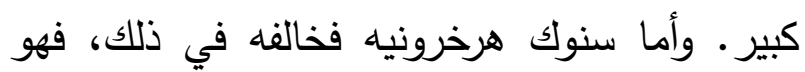

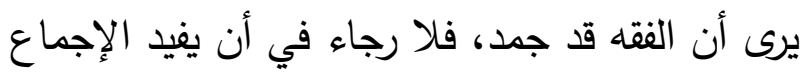
شيئاً.

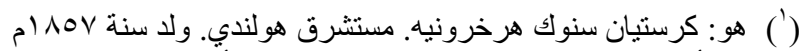

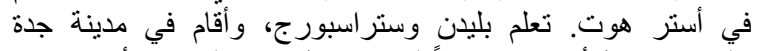

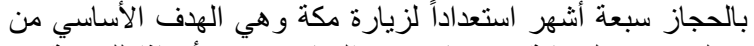

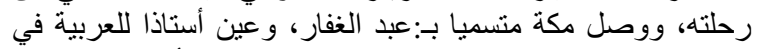

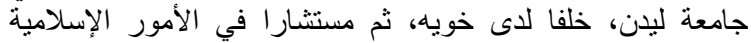

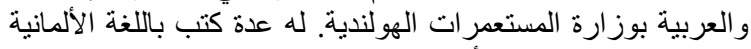

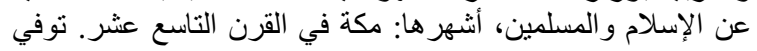

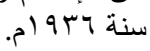

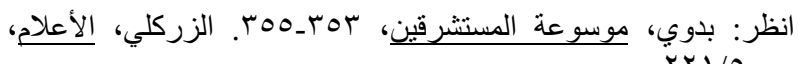
1/1/0

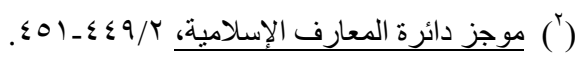


خصائص الأمة المحمدية دون غيرها(؟)، واستذلوا على ذلك بعدة أدلة، منها:

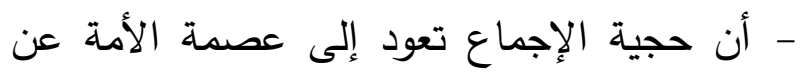
الخطأ(V)، وقد أورد الفخر الرازي(^) ثمانية عشر خبراً

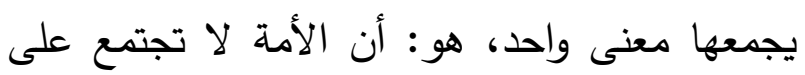
خطأ(9)، وهذه العصمة غير متحققة للأمم الأخرى؛

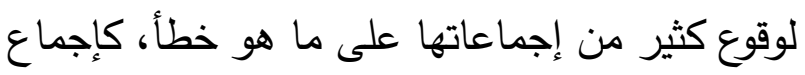

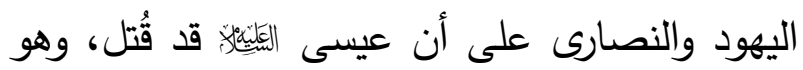

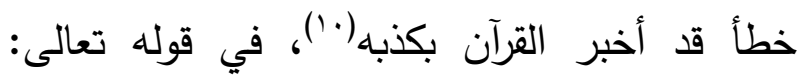

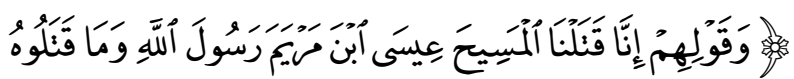

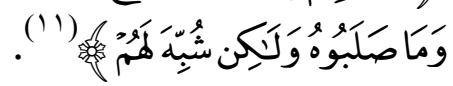

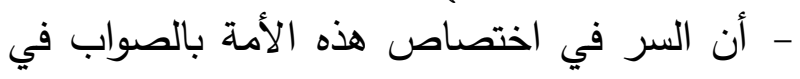

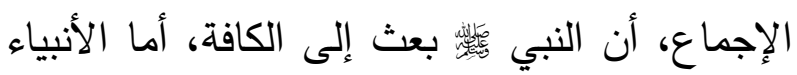

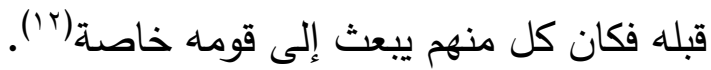

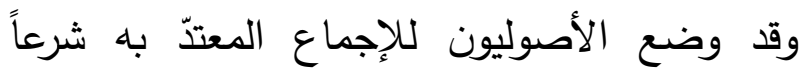

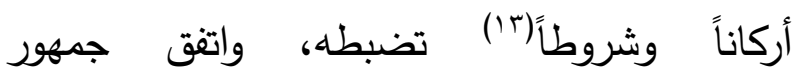

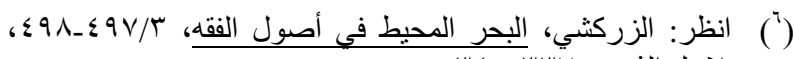

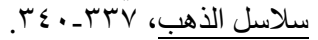

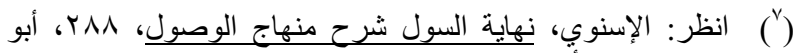

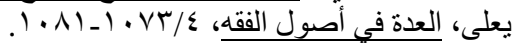

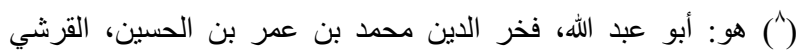

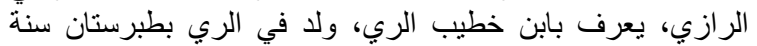

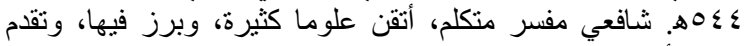

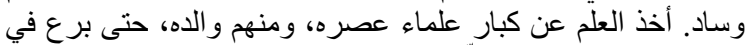

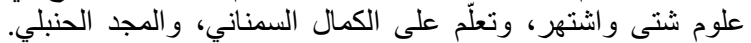

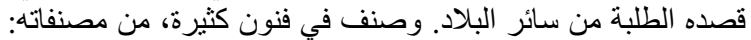
مفاتيح الغيب، وتأسيس الثقايس، والمحصول في أصول الفيرة الفقه. توفي سنة 7 . 7 هـ.

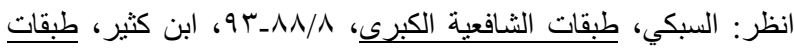

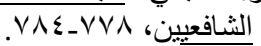

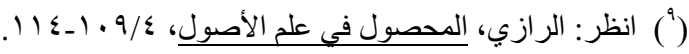

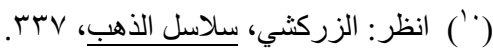

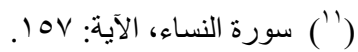

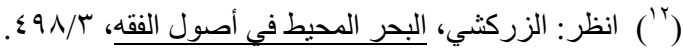

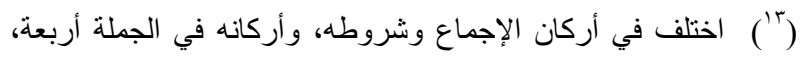

قال ابن برهان ('): "أجرى الله العادة بأن يجعل في

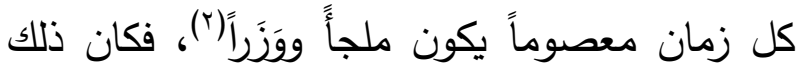
في بني إسرائيل ظاهراً، فإنه كلما انقرض نبي خلفه

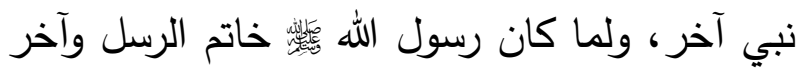
الأنبياء، فلا مطهع في وجود نبي بعده، ولا بد من ونان رسول معصوم عن الخطأ، وليس ذلك إلا الإجماع"(r).

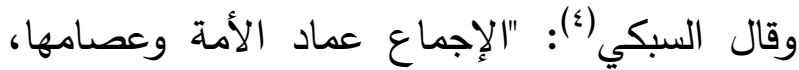
وملاذ الملة وقوامها"(ن). والإجماع من الخصائص التي اتسم بها التشريع الإسلامي. وذكر بعض الأصوليين أن الإجماع من

(1) هو: أبو الفتح، أحمد بن علي بن برهان بن الحمامي، البغدادي، لألاديا.

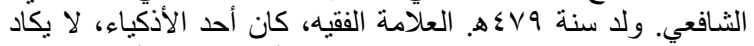

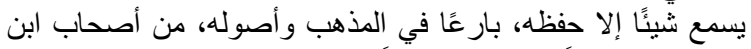

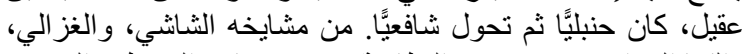

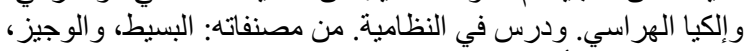

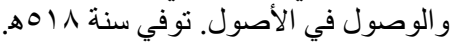

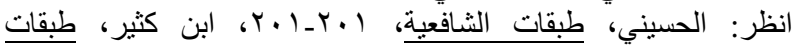

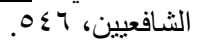

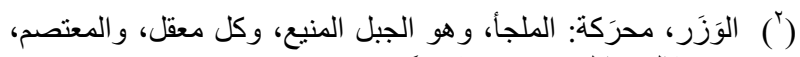

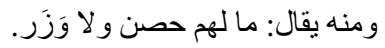

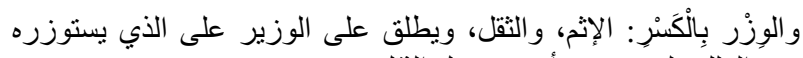

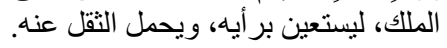

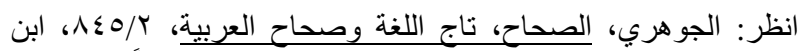

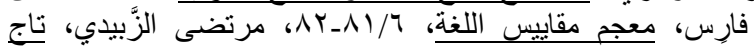

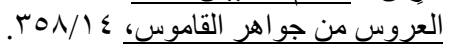

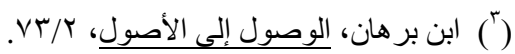

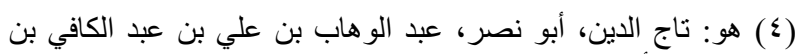

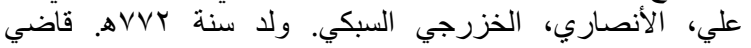

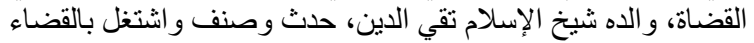

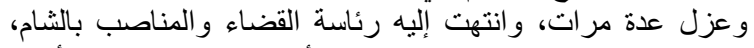

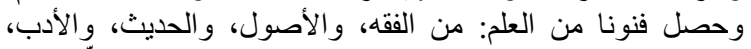

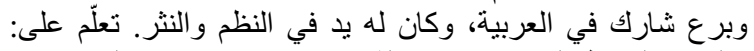

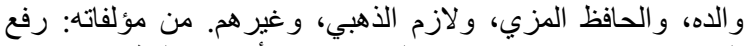

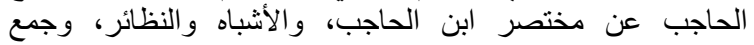

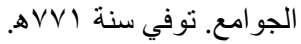

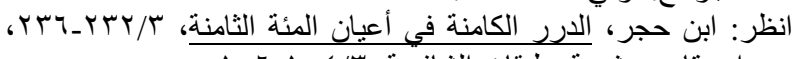

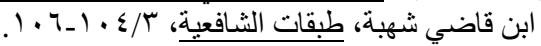

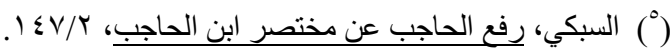


فيها، والمؤمنون مجمعون على ذلك. وكذلك كل ما أجمع عليه المسلمون فإنه لا يكون إلا حقاً موافقاً لما

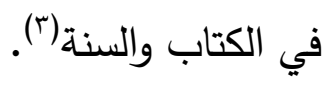
ومما قرره الأصوليون أنه لا يجوز النسخ بالإجماع؛ لأن الإجماع لا يكون إلا بعد وفاة الرسول، ووقت

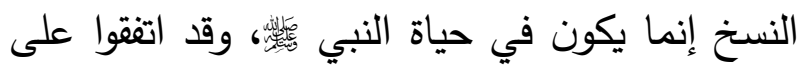
أنه لا نسخ بعد موته لهائه

\section{وبعد هذا العرض يمكن القول:} - ما ذكره ماكدونالد من أن الإجماع أحد الأصول الأربعة التي تقوم عليها العقيدة الإسلامية يفتقر إلى الدقة؛ خاصة في عصر تم فيه تحديد المصطلحات الثرعية.

نعم، يعتقد جمهور المسلمين بأن الأصول الأربعة والتي هي: (القرآن، والسنة، والإجماع، والقياس) مصادر متقق عليها للتشريع، ولكن هناك فرق بين أصول العقيدة التي هي: (الإيمان بالله، وملائكته، وكتبه، ورسله، واليوم الآخر، والإيمان بالقدر خيره

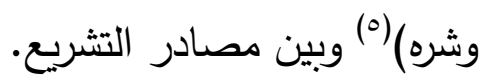
فأحكام الشريعة لها مصادر تؤخذ منها، واتقق جمهور المسلمين على أربعة منها في الجملة، وهي:

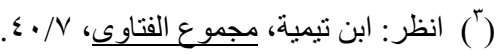

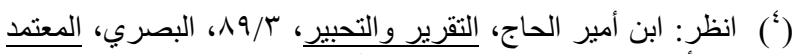

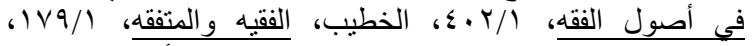

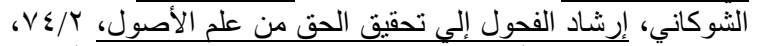

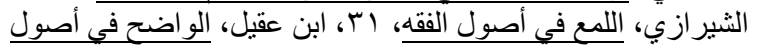

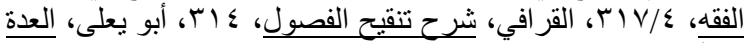

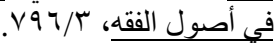

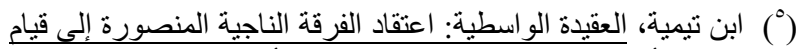

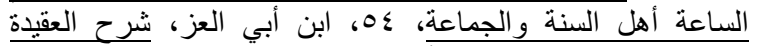

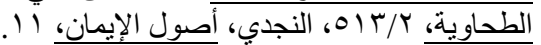

الأصوليين على أن هذه الأمة لا تجتمع إلا بدليل

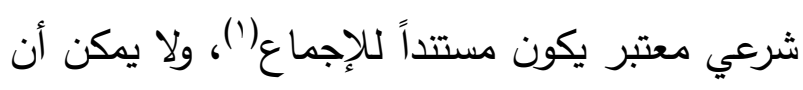
يكون إجماعها عن هوى، أو قولاً على الله بغير علم،

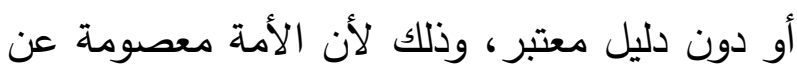
الخطأ، إذ القول على الله بدون دليل خطأ(؟). وكذلك مما قررّ الأصوليون أن مدلول الكتاب والسنة والإجماع واحد، فإن كل ما في الكتاب فالرسول في موافق له، والأمة مجمعة عليه من حيث الجملة،

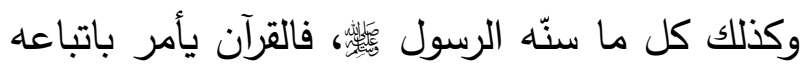

ولكل ركن شروط خاصة به، و إن لم تكن محل اتفاق جميعها، وهي

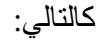

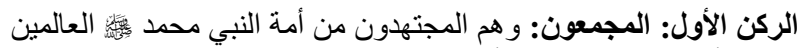

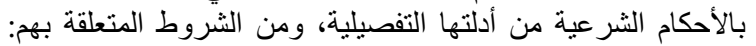

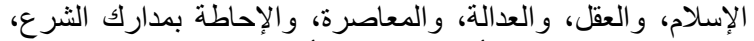
ومعرفة كيفية استثمار الأدلة واستتباط الأحكام.

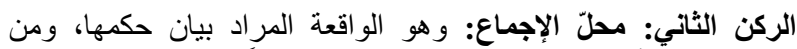

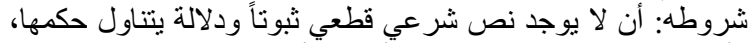

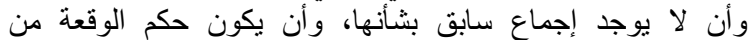

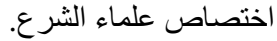

الركن الثالث: المجمع عليه: والمقصود بله به حكم الواقعة الثرعي،

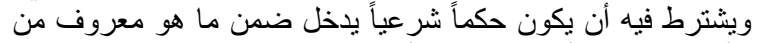

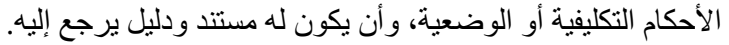

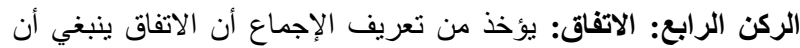

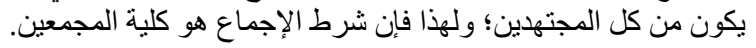

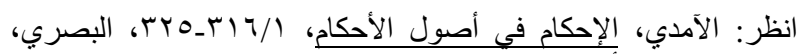

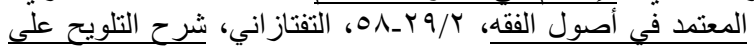

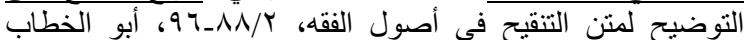

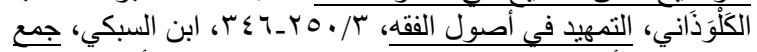

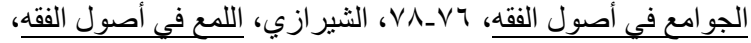

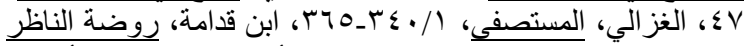

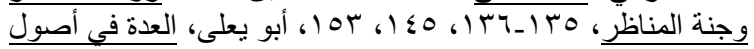

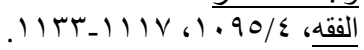

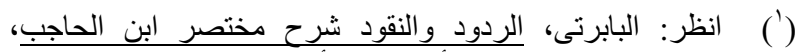

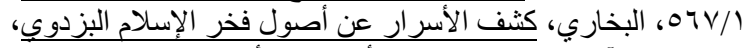

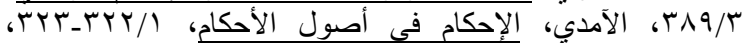

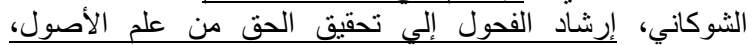

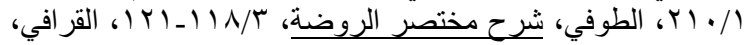

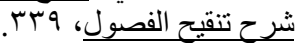

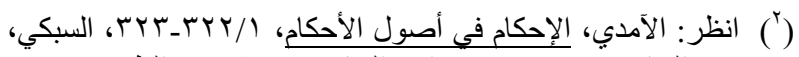

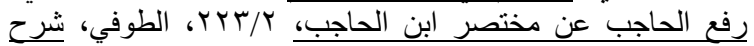

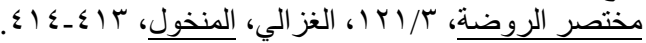


يكونون مجتمعين على القول بخلافها فلم أجدها قط" (؛). - أن ما قاله ماكدونالد من أنه يمكن عن طريق الإجماع تعديل عقائد ثابته، بل وإنشاء عقائد جديدة، وأن الإجماع أصبح عنصراً من عناصر التوفيق والتقريب بين السنة والبدع المستحدثة، بل وينسخ السنة، ينبئ عن قصور شديد في فهم معنى الإجماع الصحيح، ذلك لأنه جعل الإجماع طريقاً مستقلاً لتقرير الأحكام الشرعية، بل وجعله دليلاً بشرياً لاله

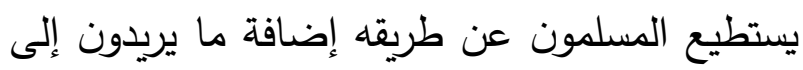
الدين وكذلك تغيير ما يرغبون، فإن هذا الكلام خطأ جملة وتفيلاً، إذ الإجماع لا يستقل بإنشاء الأحكام كمصدر مستقل. - وكذلك كلام ماكدونالد ينبئ عن قصور شديد في معند معرفة شروط الواقعة التي يجري فيها الإجماع

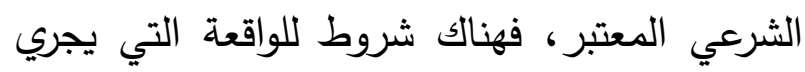

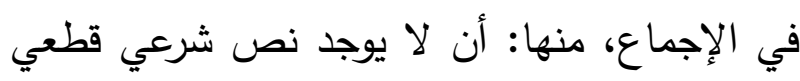

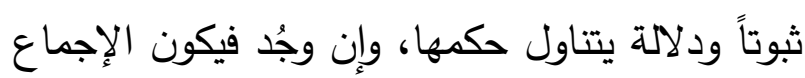

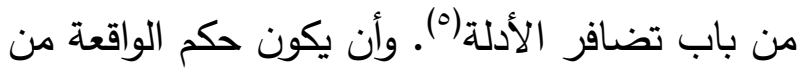

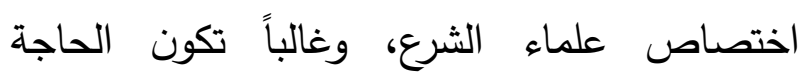
للإجماع عند وقوع نازلة جديدة لا نصّ فيها أصلاً، أو فيها نص غير قطعي (؟).

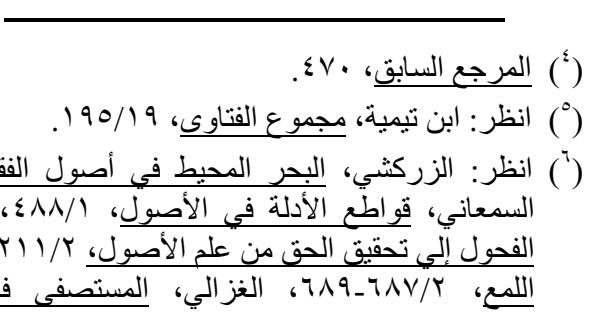

الكتاب والسنة والإجماع والقياس، فالإجماع هو أحد

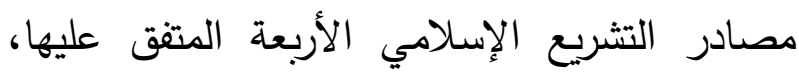
وليس أحد أصول العقيدة الإسلامية، والخلط بينهما

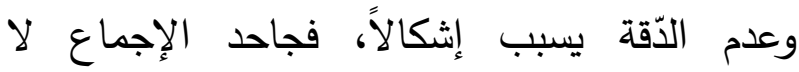
يكفر (') أما جاحد أصول العقيدة كالإيمان بالله ورسله يكفر (r). - ما ذكره ماكدونالد من أن الإجماع يرجع إلى

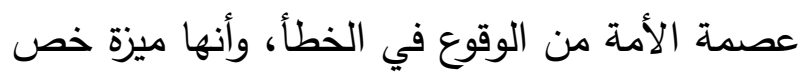
الله بها المسلمين، صحيح. - أن الإجماع بالصفة التي ذكرها ماكدونالد غير

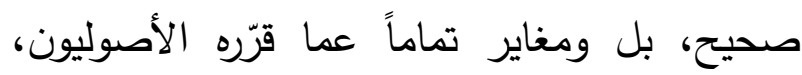
فالإجماع عند الأصوليين لا بد أن يكون له سند من فن الهن

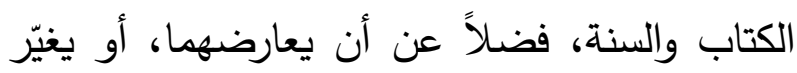

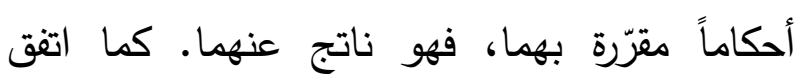
الأصوليون أيضاً على أنه لا يقدم على الكياب

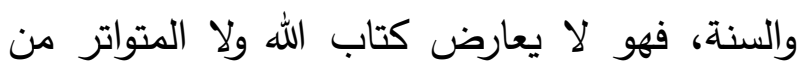
سنن النبي

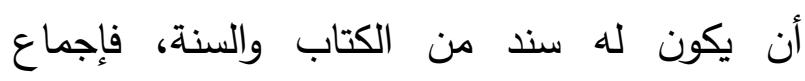
المسلمين لا يمكن أبداً أن ينعقد على خلاف الكتاب لهن

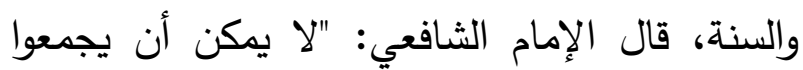

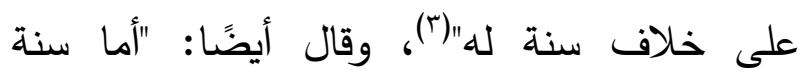

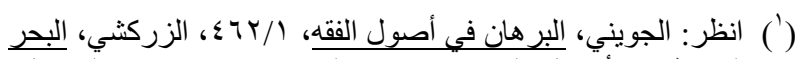

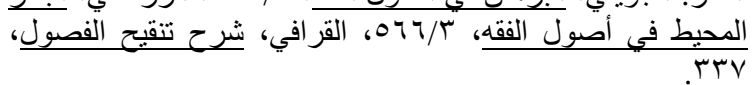

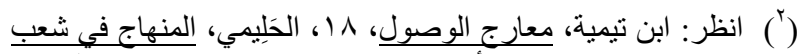

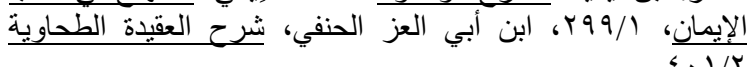

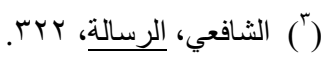


القرآن نفسه أن النبي على ذلك المسلمون.

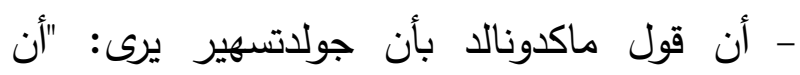
الإجماع يمكن أن يكون له شأن كبير" إن كان قائناً

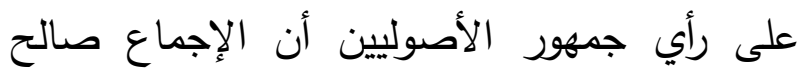
للتطبيق في كل عصر (r)، فهو قول صحيح. وإن كان يعني ما ذكره ماكدونالا -مما سبق تفسيره

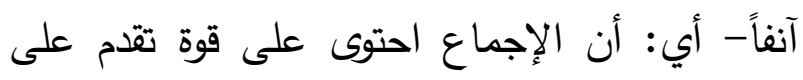
الكتاب والسنة، ومن خلاله يمكن تغيير ما في القرآن والسنة، فإنه زعم باطل (ई). وأما رأي سنوك هركروني الذي ذهب إلى باطى أن الفقه قد

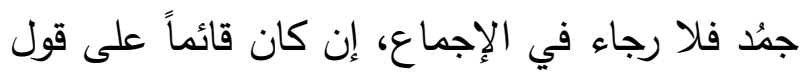

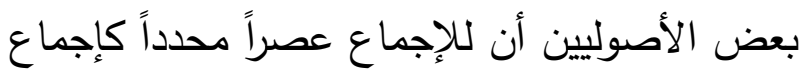
الصحابة، وأنه لا يمكن تطبيقه في أي عصر الهر بعده(o)، فهذا القول له وجه اعتبره بعض الأصوليين. وخلاصة القول أن هذه الدعوى فيها طعن للشربعة

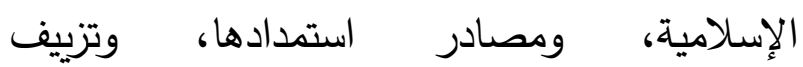
المصطلحات الإسلامية والتراث الحضاري للى الإن المسلمين، للتشويش على معتقداتهم وفقدان الثقة بقيمه ومبادئهم الدينية، وهذه الدعوى منتشرة عند

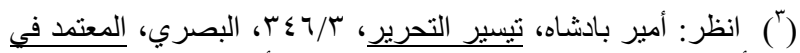

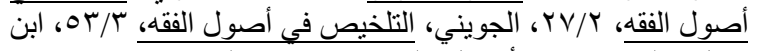

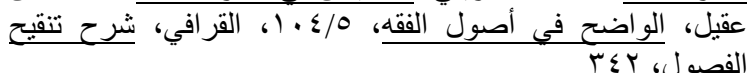

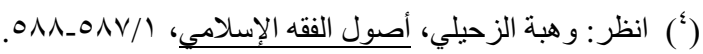

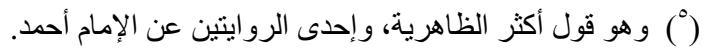

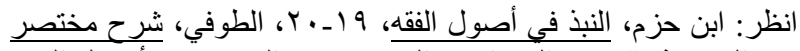

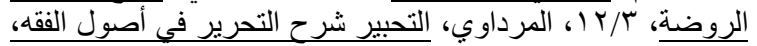

- أن قول ماكدونالد أنه بالإجماع يمكن الدكم على ألى

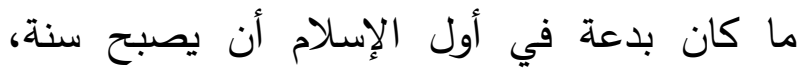

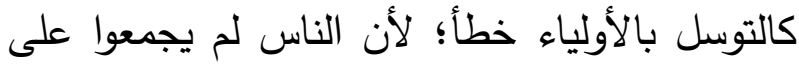

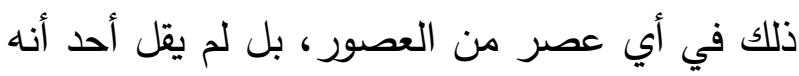

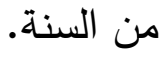
- أن عصمة المسلمين عن الخطأ التي قررها

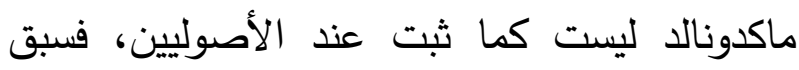
إيضاح عصمة إجماع هذه الأمة عن الخطأ، وأنه

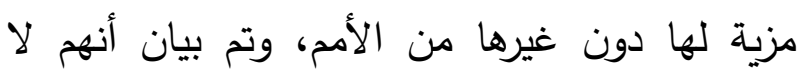

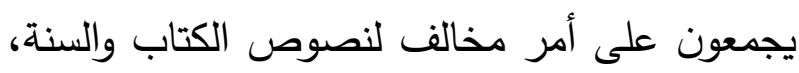

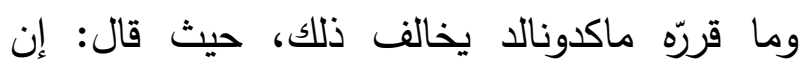
الإجماع قد ينحرف عن نصوص واضحة في القرآن الكريم. فإنه زعم غير صحيح.

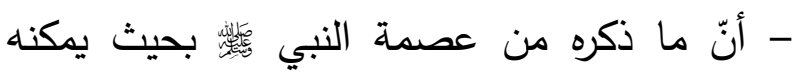
إقرار أحكام على خلاف نصوص القرآن الكريم، مجانب للصواب، فالله سبحانه وتعالى أمر الرسول الكران

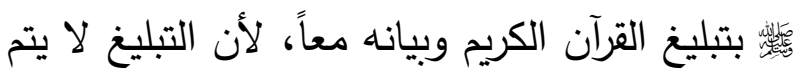
إلا بالبيان والتبليغ كان بتلقين آيات القرآن، أما البيان

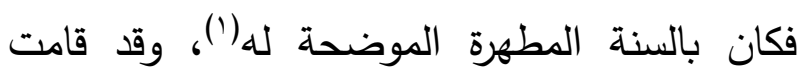

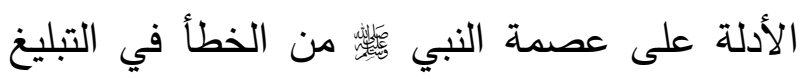

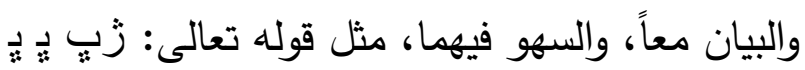

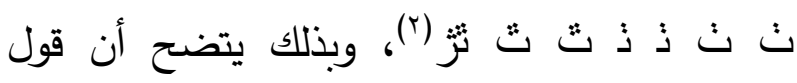

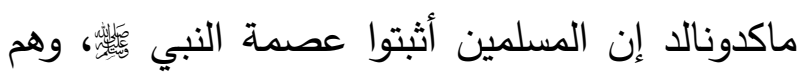
بذلك انحرفوا عن القرآن، قول باطل، بل قد قرّز 


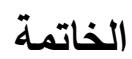

في هذا المقام، وقد آن الآوان لأن يبلغ هذا البحث

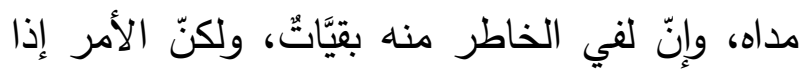

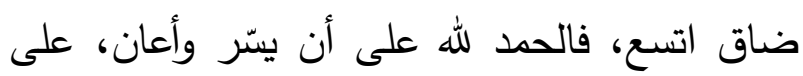
تجميعه، وكتابته، وإخراجه للنور، وأسأل الله القبول، لـأل

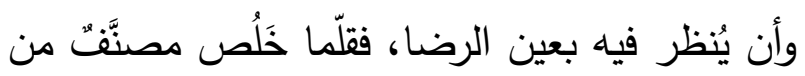

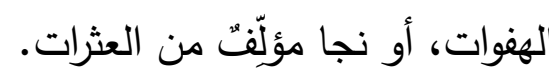

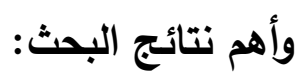
- أن دائرة المعارف الإسلامية خطيرة؛ حيث تحتوي على أخطاء كبيرة، ودسائس مريبة. - أن ما ورد في دائرة المعارف الإسلامية عن مكانة الإجماع وحقيقته يدلّ على فهم سقيم وغير صحيح، بل منحرف انحرافاً كبيراً عن الصواب، وذلك بتحميل

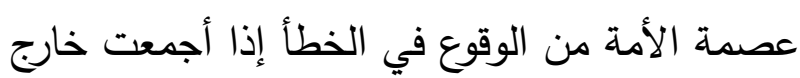

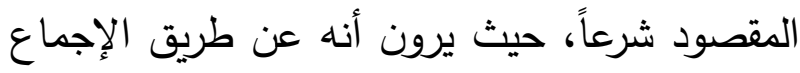

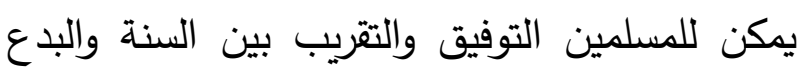

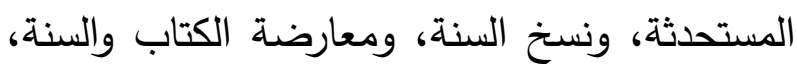
بل وبناء شريعة جديدة، وإنشاء عقائد جديدة، بشرط الإجماع على ذلك، والصحيح غير ذلك تماماً.

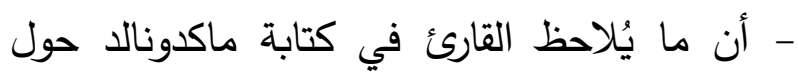

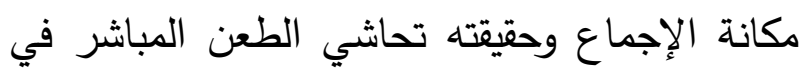
هذا الدليل، وإبداء قدر من الاحترام له في الظاهر، والاستعاضة عن ذلك بطعون وتشويهات غير مباشرة، وذلك عن طريق ذكر ما يترتب على اعتبار الإجماع من كونه معصوماً عن الخطأ.
العديد من المستشرقين في دائرة المعارف وفي غيرها

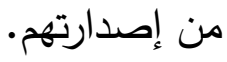
وقد عارض غير واحد من الباحثين المعاصرين الغيورين على الدين الإسلامي ومصادره مادير ما ذكره ماكدونالد وغيره من المستشرقين، وكانت هناك عدة الإستين

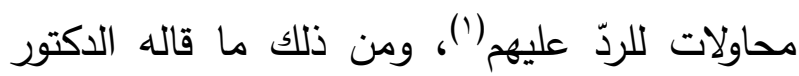
وهبة الزحيلي: للمستشرقين في الإجماع كلام مزخرف، منشؤه التصورات الوهمية، وغايته قلب الحقائق، وتشويه الأفكار الإسلامية، وإيهام الناس وتهوه

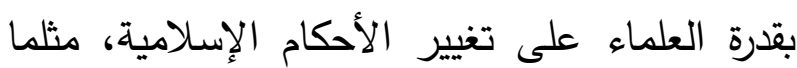

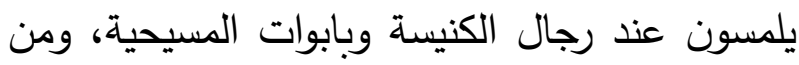
ذلك ما قاله جولد تسيهر: سوف يرى بلا شك أن

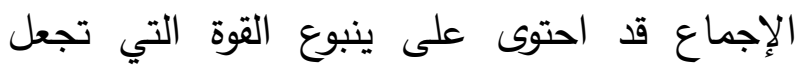

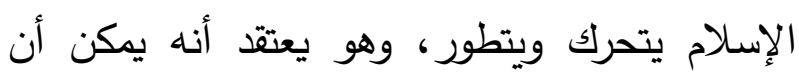

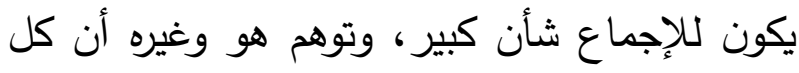

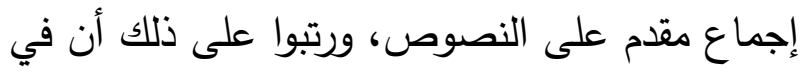

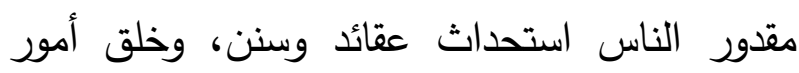
كثيرة بطريقة تفكيرهم واتفاقهم في هذا التفكير، هذا

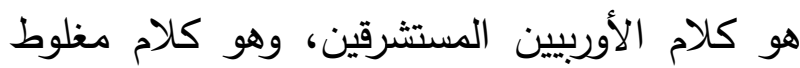
ومردود (r) (ب)

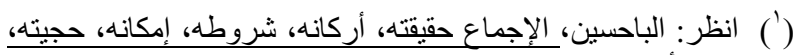

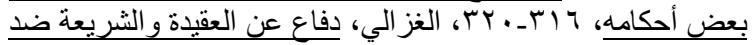

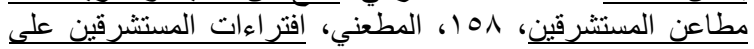

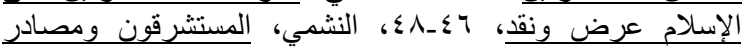

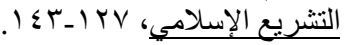

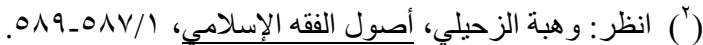




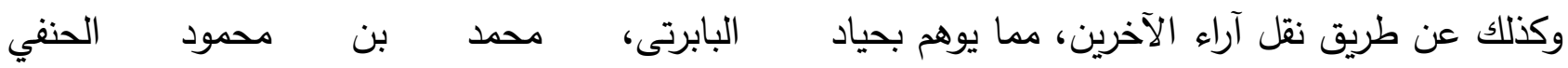

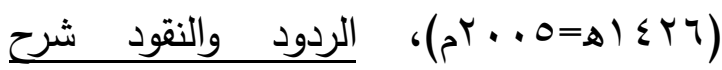
المتكلّم وموضوعيته، مما يوقعها في نفس القارئ مختصر ابن الحاجب، تحقيق: ضيف الله بن موقع الوثوق، ولعلّ هذا المنزع الذي لم يظهر صالح بن عون العمرى، ترحيب بن ربيعان الدوسري، الرياض: مكتبة الرشد.

الباجي، سليمان بن خلف (10) (1900 (م) أ، بوضوح في المؤلفات الاستشراقية الأخرى، بُني على ما تحظى به دائرة المعارف من تداول واسع بين المسلمين، فروعيت فيه المشاعر العامة، ولكن في إحكام الفصول في أحكام الأصول، تحقيق: عبد المجيد تركي، طن بيروت: دار الغرب حقيقة الحال، فإن هذا المسلك ريّما ضرره أبلغ من رئ رئ الطعن المباشر، لأنه مُسْتَخْفِ بظواهر الاعتدال الإسلامي. والموضوعية، وهو ما ينبغي الحذر منه والتنبيه إليه.

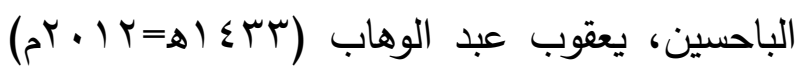
وأهم توصية في البحث: إيصال رسالة فكرية إلى ب، الإجماع حقيقته، أركانه، شروطه، إمكانه، حجيته، بعض أحكامه، طب، الرياض: مكتبة كافة الباحثين المخلصين في الأمة لكي يتعاونوا من أجل استبدال دائرة المعارف الإسلامية (محل الدراسة) بدائرة معارف إسلامية، يكتبها ويشرف

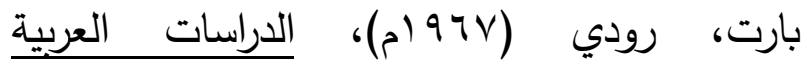
والإسلامية في الجامعات الألمانية، ترجمة: مصطفى ماهر، القاهرة: دار الكتاب العربي.

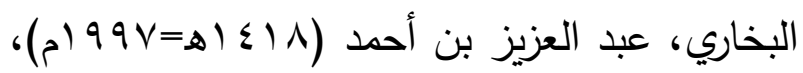
كشف الأسرار عن أصول فخر الإسلام البزدوي، تحقيق: عبد الله محمود محمد عمر، بيروت: دار الكتب العلمية. بدوي، عبد الرحمن (999) أ، موسوعة المستشرقين، طس، بيروت: دار العلم للماليين.

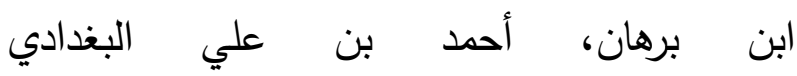

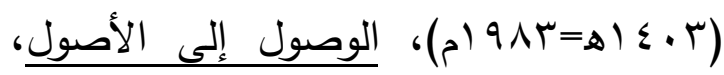
تحقيق: عبد الحميد علي أبو زنيد، الرياض:

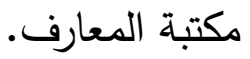
قائمة المراجع عليها المسلمون أنفسهم.

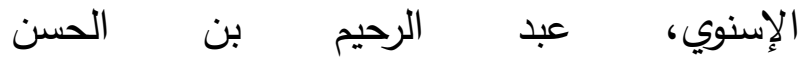

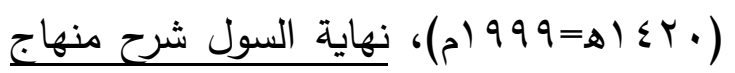
الوصول، بيروت: دار الكتب العلمية. الآمدي، علي بن محمد (ع ·ـ اهـ)، الإحكام في أصول الأحكام، تحقيق: سيد الجميلي، بيروت:

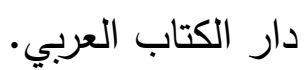

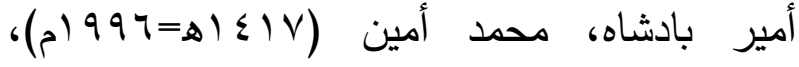
تيسير التحرير، بيروت: دار الفكر.

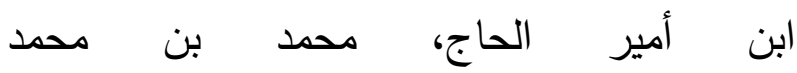

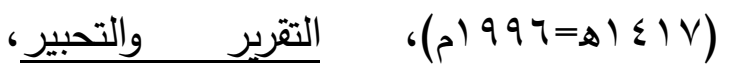
ط[بدون]، بيروت: دار الفكر • 
الصحاح، تاج اللغة وصحاح العربية، تحقيق: أحمد عبد الغفور عطار، طء، بيروت: دار ارهار العلم للملايين. - العمد

جويدي، ميكائيل أنجلو (9 (بانه)، علم الشرق وتاربخ العمران، القاهرة: المطبعة السلفية الهاتية ومكتبتها.

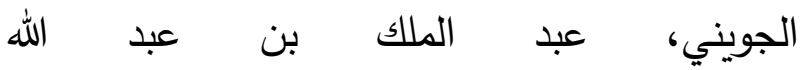

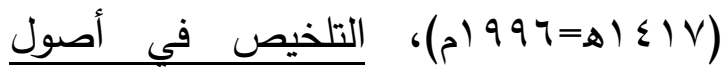
الفقه، تحقيق: عبد الله جولم النبالي وبشير أحمد الهدي العمري، ط: [بدون]، بيروت: دار البشائر الإسلامية.

(1) 1 أه)، البرهان في أصول الفقه، تحقيق: عبد العظيم محمود الديب، طع، المنصورة: الوفاء.

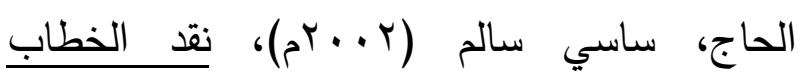

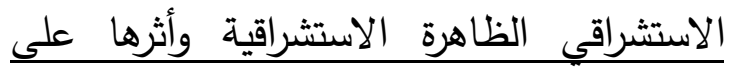

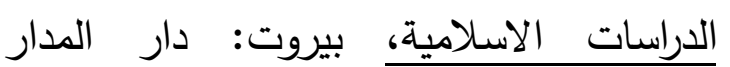
الإسلامي.

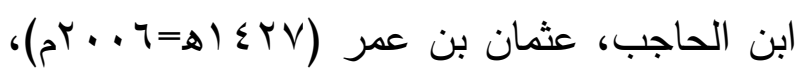

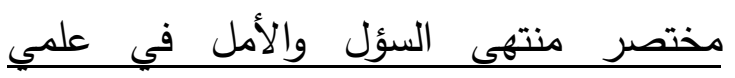
الأصول والجدل، تحقيق: نذير حمادو، بيروت:

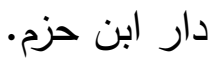

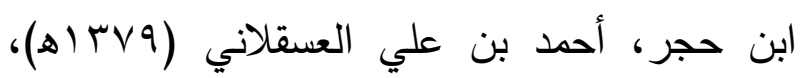
فتح الباري شرح صحيح البخاري، ط [بدون]، بيروت: دار المعرفة.

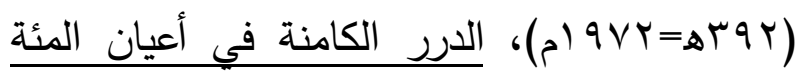

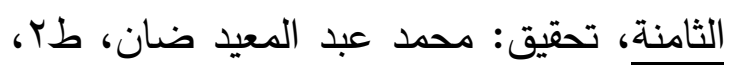

البزدوي، علي بن محمد (تاريخ النشر [بدون])، كنز

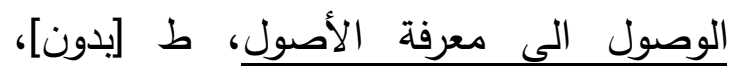
كراتثي: مطبعة جاويد بريس.

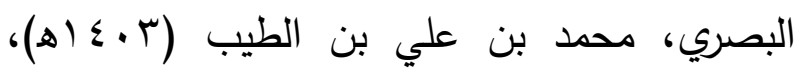

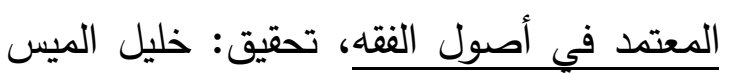
بيروت: دار الكتب العلمية.

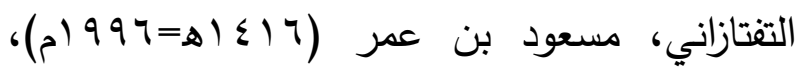
شرح التلوبح على التوضيح لمتن التنقيح في أصول الفقه، تحقيق: زكريا عميرات، بيروت: دار الكتب العلمية. التميمي، عبد الرحمن بن حسن، المطلب الحميد في بيان مقاصد التوحيد، مدينة النشر [بدون]: دار الهذاية.

ابن تيمية، أحمد بن عبد الحليم بن عبد السلام

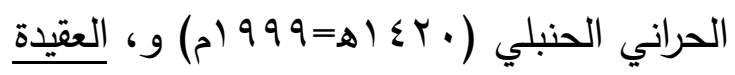
الواسطية: اعتقاد الفرقة الناجية المنصورة إلى الى الهي قيام الساعة أهل السنة والجماعة، تحقيق: أبي البئه محمد أشرف بن عبد المقصود، طب، الرياض: أضواء السلف.

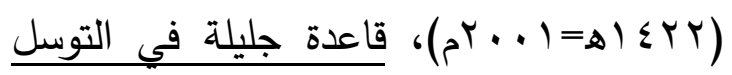
والوسيلة، تحقيق: ربيع بن هادي عمير المدخلي، عجمان: مكتبة الفرقان.

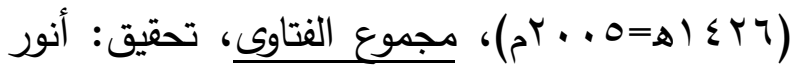
الباز، عامر الجزار، طس، مدينة النشر [بدون]:

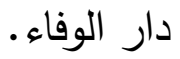

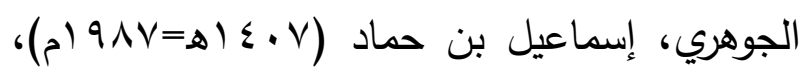


الرازي، محمد بن عمر (·ـ (هـ)، المحصول في علم الأصول، تحقيق: طنه بن جابر فياض العلواني، الرياض: جامعة الإمام محمد بن الاهن

$$
\text { سعود الإسلامية. }
$$

ابن رجب، عبد الرحمن بن أحمد الحنبه الحنبلي

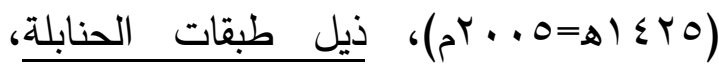
تحقيق:عبد الرحمن بن سليمان العثيمين، الرياض: مكتبة العبيكان. - ان.

الزَّبيدي، محمّد بن محمّد الحسيني مرتضى (تاريخ النشر [بدون])، تاج العروس من جواهر القاموس، تحقيق: مجموعة من المحققين، ط [بدون]، مدينة النشر [بدون]: دار الهداية.

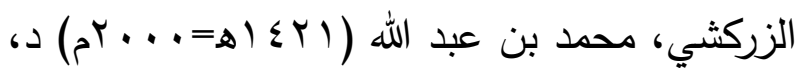

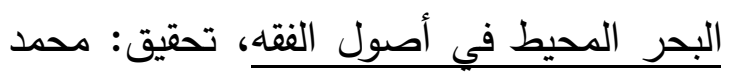
محمد تامر، ط [بدون]، بيروت: دار الكتب

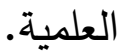

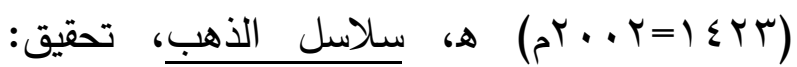
محمد المختار بن محمد الأمين الشنقيطي، طץ، الناشر [بدون].

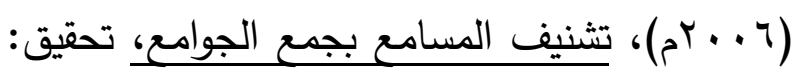
سيد عبد العزيز وعبد الله ربيع، طب مدينة النشر [بدون]: مؤسسة قرطبة.

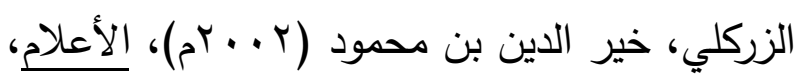
طه 1، مدينة النشر [بدون]: دار العلم للملايين. زقزوق، محمود حدي (تاريخ النشر: [بدون])، الاستشراق والخلفية الفكرية للصراع الحضاري،
حيدر أباد: مجلس دائرة المعارف العثمانية.

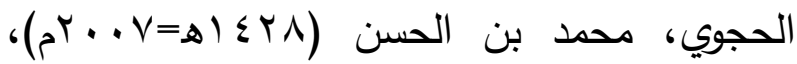
الفكر السامي في تاربخ الفقه الإسلامي، اعتنى به: أيمن صالح شعبان، طץ بيروت: دار

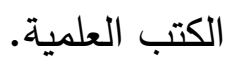
ابن حزم، علي بن أحمد الأندلسي (0. (اه)، النبذ

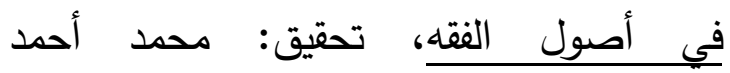
عبد العزيز ، بيروت: دار الكتب العلمية. الحسيني، إسحاق موسى (97V (م)، الاستشراق نشأته وتطوره وأهدافه، مدينة النشر لبدون]: مطبعة الأزهر .

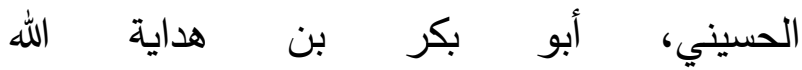

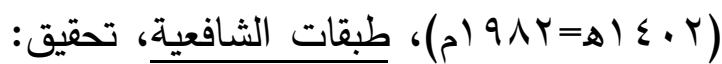
عادل نويهض، طس، بيروت: دار الآفاق

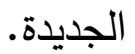

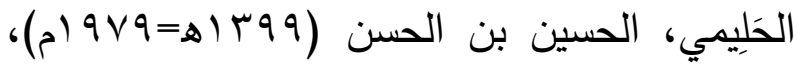
المنهاج في شعب الإيمان، تحقيق: حلمي محمد فودة، مدينة النشر [بدون]: دار الفكر . أبو الخطاب الكَلْوَذَاني، محفوظ بن أحمد بن الحسن

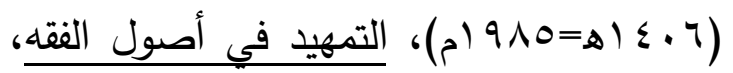
تحقيق: مفيد محمد أبو عمشة، محمد بن علي بن إبراهيم، مكة المكرمة: مركز البحث العلمي وإحياء التراث الإسلامي - جامعة أم القرى.

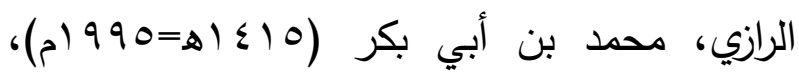

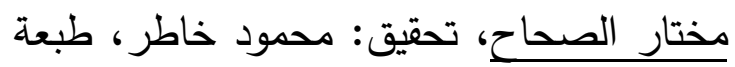
جديدة، بيروت: مكتبة لبنان. 
السمعاني، منصور بن محمد (1) (1 أه=و999 (م))،

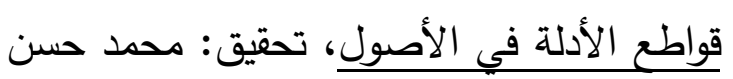

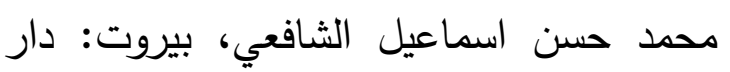

$$
\text { الكتب العلمية. }
$$

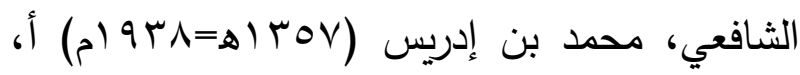

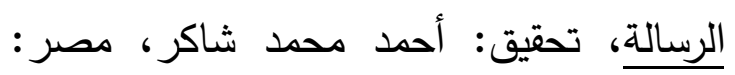
مطبعة مصطفى البابي الحلبي وأولاده.

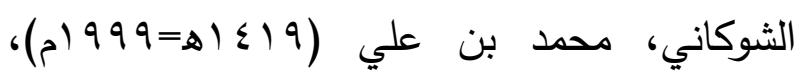

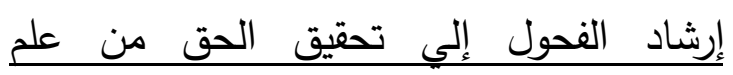

الأصول، تحقيق: أحمد عزو عناية، تقديم:

خليل الميس، وولي الدين صالح فرفور ، دمثق:

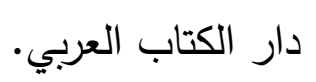

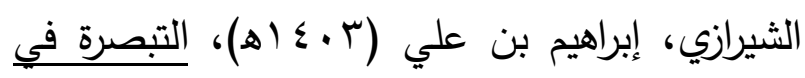

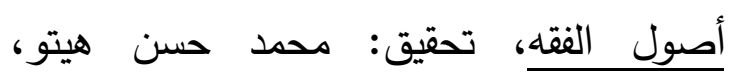

$$
\text { دمشق: دار الفكر . }
$$

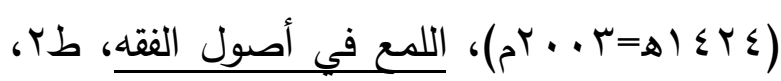

$$
\text { بيروت: دار الكتب العلمية. }
$$

طعيمة، صابر (تاريخ النشر [بدون])، أخطار الغزو

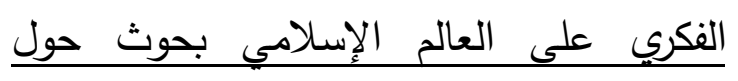
العقائد الوافدة، ط [بدون]، مدينة النشر [بدون]: عالم الكتب. - مان.

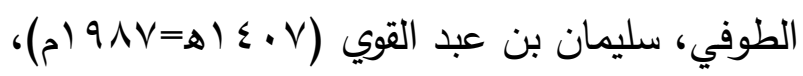

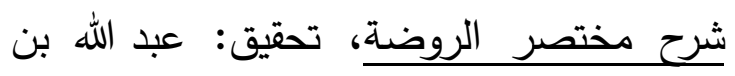
عبد المحسن التركي، مدينة النشر [بدون]: مؤسسة الرسالة.

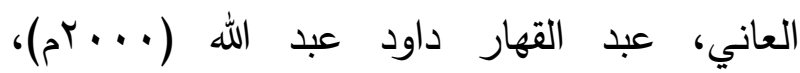

ط [بدون] القاهرة: دار المعارف.

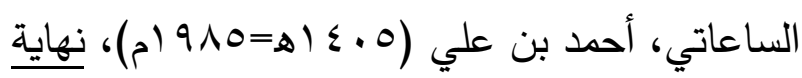

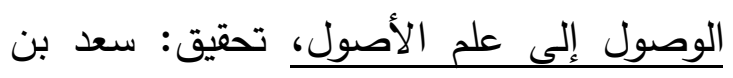

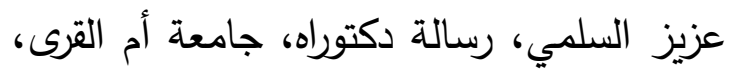
مكة المكرمة. السبكي، عبد الوهاب بن علي (باءك اهـ) أ، طبقات

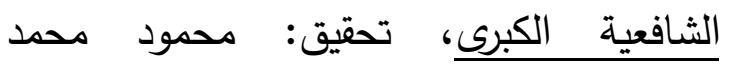
الطناحي، عبد الفتاح محمد الحلو، طب مدينة النشر [بدون]: هجر للطباعة.

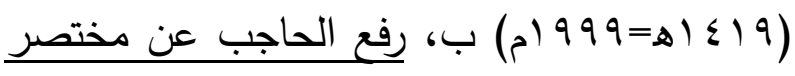
ابن الحاجب، تحقيق: علي محمد معوض، عادل أحمد عبد الموجود، بيروت: عالم الكتب.

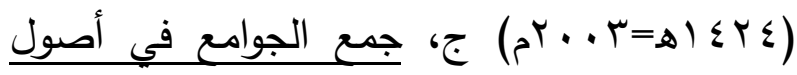

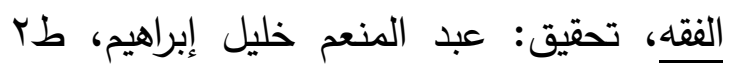
بيروت: دار الكتب العلمية.

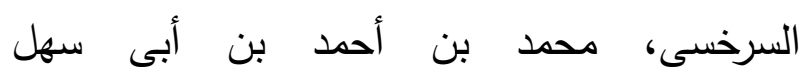

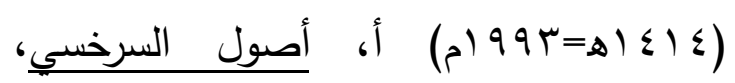
بيروت: دار الكتب العلمية. سمايلوفتش، أحمد (تاريخ النشر [بدون])، فلسفة

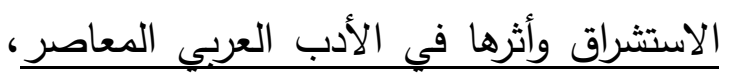

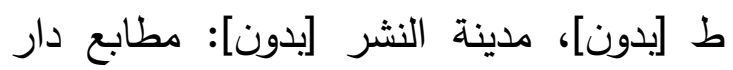
المعارف.

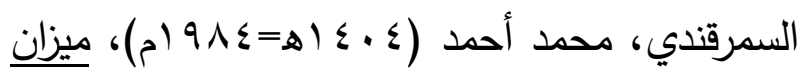
الأصول في نتائج العقول في أصول الفقه، تحقيق: عبد الملك عبد الرحمن أسعد السعدي، رسالة دكتوراه، جامعة أم القرى، مكة المكرمة. 


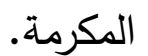

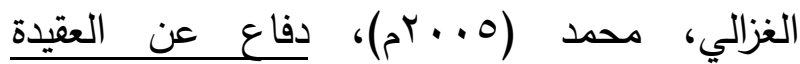
والثربعة ضد مطاعن المستشرقين، طVا،

القاهرة: نهضة مصر •

الغزالي، محمد بن محمد (

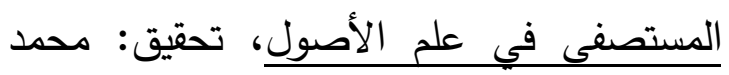

سليمان الأشقر ، بيروت: مؤسسة الرسالة.

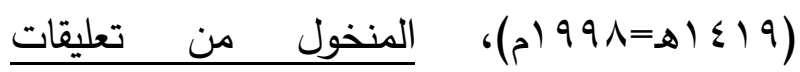

الأصول، تحقيق: محمد حسن هيتو، طب،

بيروت، دمشق: دار الفكر المعاصر، دار

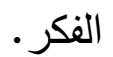

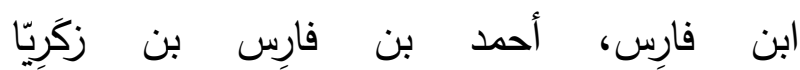

تحمة

تحقيق: عبد السَّلام محمد هَارُون، مدينة النشر

[بدون]: اتحاد الكتاب العرب.

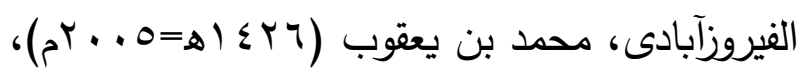

القاموس المحيط، تحقيق: مكتب تحقيق التراث

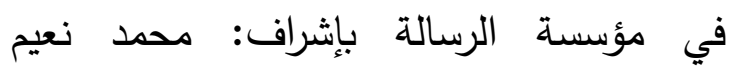

العرقسُوسي، طه، بيروت: مؤسسة الرسالة.

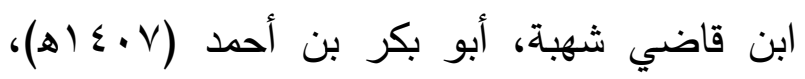

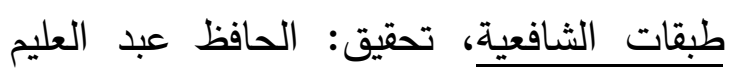

خان، بيروت: عالم الكتب.

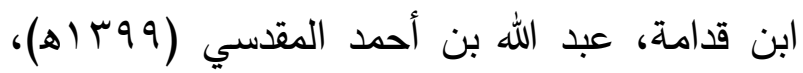

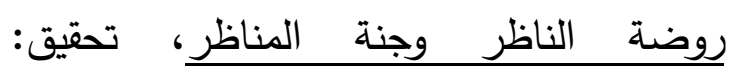

عبد العزيز عبد الرحمن السعيد، طب، الرياض:

جامعة الإمام محمد بن سعود.
الاستشراق والدراسات الإسلامية، عمّان: دار

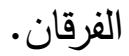

ابن عبد البر، يوسف بن عبداله القرطبي

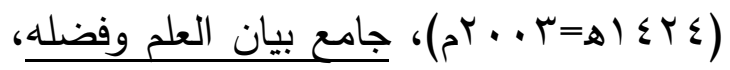
تحقيق: فواز أحمد زمرلي، مدينة النشر [بدون]: مؤسسة الريان - دار ابن حزم.

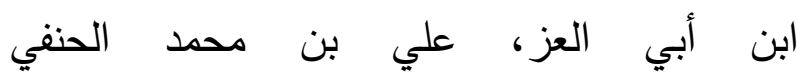

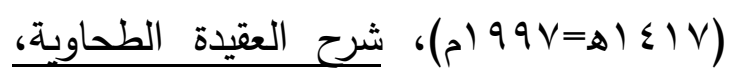
تحقيق: شعيب الأرنؤوط، عبد الله بن المحسن التركي، ط. ا، بيروت: مؤسسة الرسالة.

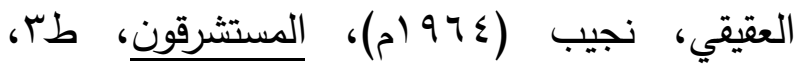
القاهرة: دار المعارف.

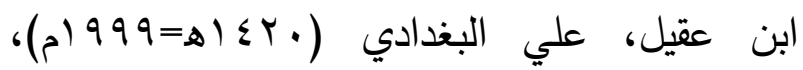
الواضح في أصول الفقه، تحقيق: عَبد الله بن الن الن عَبد المُحسن التركي، بيروت: مؤسسة الرسالة. ابن العماد، عبد الحي بن أحمد العكري الحنبلي (7 ، ـ (ه)، شذرات الذهب في أخبار من ذهب،

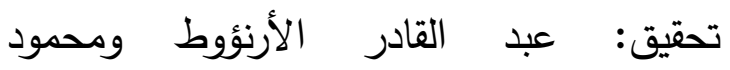
الأرناؤوط، ط: [بدون]، دمشق: دار ابن كثير •

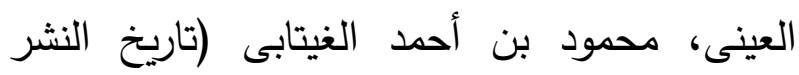

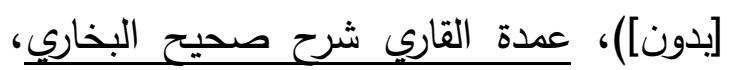
بيروت: دار إحياء التراث العربي. لئرون

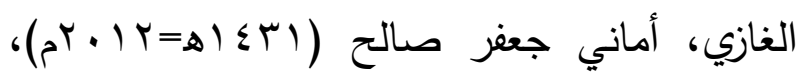
الدولة العثمانية من خلال كتابات المستشرقين في دائرة المعارف الإسلامية عرض من ونقد وتحليل، رسالة دكتوراه، جامعة أم القرى، مكة الإنداهي 
افتراءات المستشرقين على الإسلام عرض ونقد،

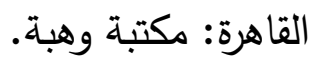

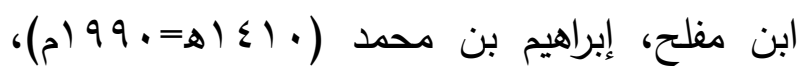

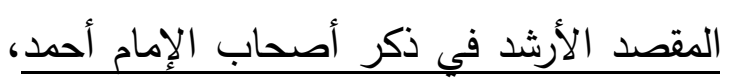
تحقيق: عبد الرحمن بن سليمان العثيمين، الرياض: مكتبة الرشد.

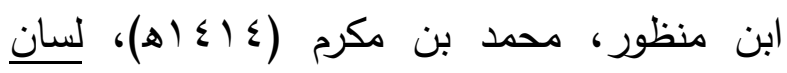
العرب، طץ بيروت: دار صادر •

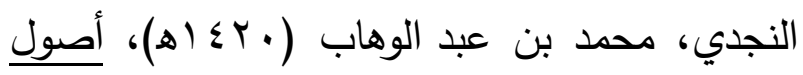

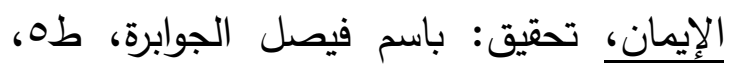

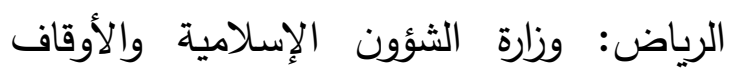
والدعوة والإرشاد.

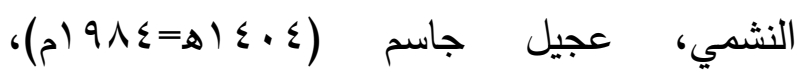

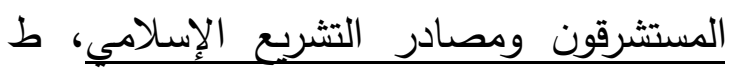
[بدون]، الكويت: المجلس الوطني للثقافة والفنون والآداب.

وهبة الزحيلي، أصول الفقه الإسلامي، (دمشق: دار

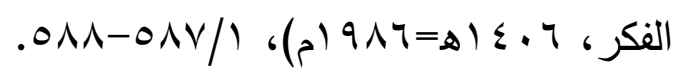

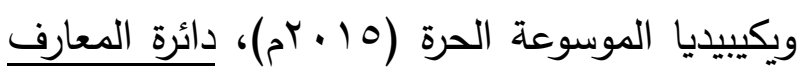

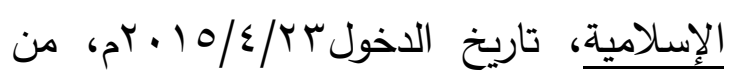

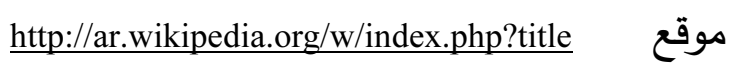
"oldid=15375210\& أبو يعلى، محمد بن الحسين الفراء القاضي

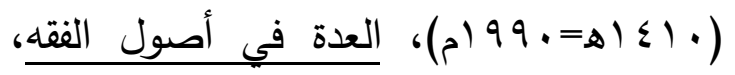

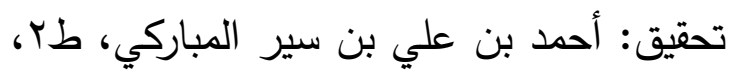
مدينة النشر [بدون]: دار النشر [بدون].
القرافي، أحمد بن إدريس بن عبد الرحمن

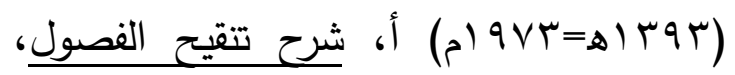
تحقيق: طه عبد الرؤوف سعد، مدينة النشر [بدون]: شركة الطباعة الفنية المتحدة.

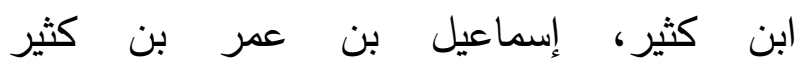

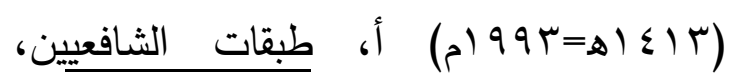
تحقيق: أحمد عمر هاشم، محمد زينهم محمد عزب، مدينة النشر [بدون]: مكتبة الثقافة

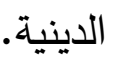

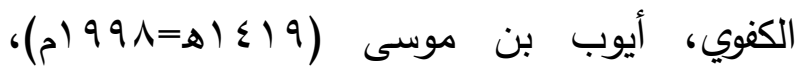

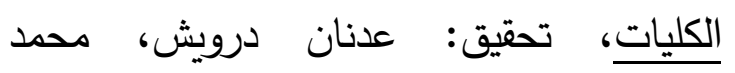
المصري، بيروت: مؤسسة الرسالة.

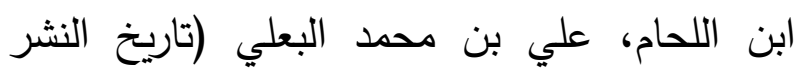

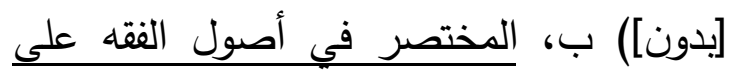
مذهب الإمام أحمد بن حنبل، تحقيق: محمد

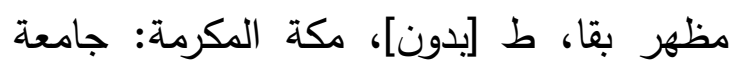

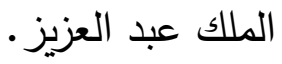

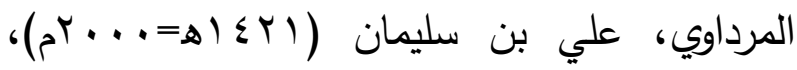
التحبير شرح التحربر في أصول الفقه، تحقيق: عبد الرحمن الجبرين، عوض القرني، أحمد لئريز السراح، ط [بدون]، الرياض: مكتبة الرشد.

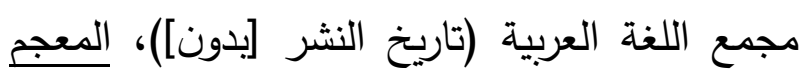

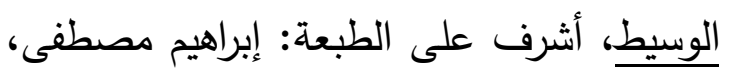

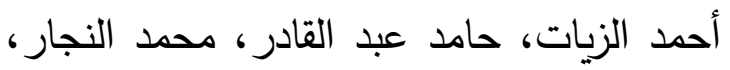
ط [بدون]، مدينة النشر [بدون]: دار الدعوة.

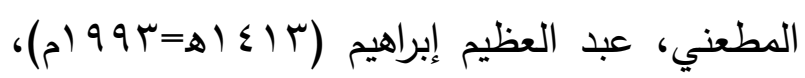




\title{
The orientalists' view of the status and truth of consensus through the circle of Islamic knowledge A Critical Study
}

\author{
Hanadi Bint Rasheed bin Rasheed Al Saadi \\ Faculty of Arts and Humanities \\ Jeddah - Kingdom of Saudi Arabia
}

\begin{abstract}
Praise be to Allah, Lord of the Worlds, and prayers and peace be upon the Seal of Prophets and Messengers, and after:

This research is a radical fundamentalist study that dealt with the Orientalists' view of the status and truth of consensus through the Islamic Knowledge Department. It contains an introduction, two papers, a conclusion, a bibliography, and the contents, and the first topic: the definition of consensus, Orientalism, and the circle of Islamic knowledge. The second topic: the orientalists' view of the status of the consensus, its truth, and criticism of this vision. The conclusion and the main findings of the research and recommendation.

The method used in this research is a fundamentalist Critical study. It is necessary to mention the texts on the status and truthfulness of the consensus in the circle of Islamic knowledge, then explain it, and then criticize it, and then identify and discuss aspects of health and error.

The most important result of this research is that what is mentioned in the Islamic knowledge circle about the status and truth of the consensus is completely devoid of correctness. It is stated that by consensus, Muslims can establish a new law and amend and change fixed beliefs in the Islamic religion. Sunnah and heresy, and that consensus can oppose the book and the Sunna and submit them.

The most important recommendation in the research: the delivery of an intellectual message to all researchers dedicated in the nation to cooperate in order to replace this circle with an Islamic knowledge circle, written and supervised by the Muslims themselves.
\end{abstract}

